\title{
The loss of Normandy and the invention of Terre Normannorum, 1204
}

Article

Accepted Version

Moore, A. K. (2010) The loss of Normandy and the invention of Terre Normannorum, 1204. English Historical Review, 125 (516). pp. 1071-1109. ISSN 0013-8266 doi: https://doi.org/10.1093/ehr/ceq273 Available at https://centaur.reading.ac.uk/16623/

It is advisable to refer to the publisher's version if you intend to cite from the work. See Guidance on citing.

To link to this article DOI: http://dx.doi.org/10.1093/ehr/ceq273

Publisher: Oxford University Press

All outputs in CentAUR are protected by Intellectual Property Rights law, including copyright law. Copyright and IPR is retained by the creators or other copyright holders. Terms and conditions for use of this material are defined in the End User Agreement.

\section{www.reading.ac.uk/centaur}

\section{CentAUR}

Central Archive at the University of Reading

Reading's research outputs online 
The Loss of Normandy and the Invention of Terre Normannorum, 1204

This is a pre-copy-editing, author-produced PDF of an article accepted for publication in English Historical Review following peer review. The definitive publisher-authenticated version [T. K. Moore, 'The Loss of Normandy and the Invention of Terre Normannorum, 1204', English Historical Review (2010) CXXV (516): 1071-1109. doi: 10.1093/ehr/ceq273] is available online at: http://ehr.oxfordjournals.org/content/CXXV/516/1071.full.pdf + html

Dr. Tony K. Moore,

ICMA Centre,

Henley Business School, University of Reading,

Whiteknights,

Reading,

RG6 6BA;

t.moore@icmacentre.ac.uk 


\begin{abstract}
The conquest of Normandy by Philip Augustus of France effectively ended the 'Anglo-Norman' realm created in 1066, forcing cross-Channel landholders to choose between their English and their Norman estates. The best source for the resulting tenurial upheaval in England is the Rotulus de valore terrarum Normannorum, a list of seized properties and their former holders, and this article seeks to expand our understanding of the impact of the loss of Normandy through a detailed analysis of this document. First, it demonstrates that the compilation of the roll can be divided into two distinct stages, the first containing valuations taken before royal justices in June 1204 and enrolled before the end of July, and the second consisting of returns to orders for the valuation of particular properties issued during the summer and autumn, as part of the process by which these estates were committed to new holders. Second, study of the roll and other documentary sources permits a better understanding of the order for the seizure of the lands of those who had remained in Normandy, the text of which does not survive. This establishes that this royal order was issued in late May 1204 and, further, that it enjoined the temporary seizure rather than the permanent confiscation of these lands. Moreover, the seizure was not retrospective and covers a specific window of time in 1204. On the one hand, this means that the roll is far from a comprehensive record of terre Normannorum. On the other hand, it is possible to correlate the identities of those Anglo-Norman landholders whose English estates were seized with the military progress of the French king through the duchy in May and June and thus shed new light on the campaign of 1204. Third, the article considers the initial management of the seized estates and highlights the fact that, when making arrangements for the these lands, John was primarily concerned to maintain his freedom of manoeuvre, since he was not prepared to accept that Normandy had been lost for good.
\end{abstract}




\section{The Loss of Normandy and the invention of terre Normannorum, 1204 *}

In May and June 1204 King Philip 'Augustus' of France overran Normandy, bringing to an end the 'Anglo-Norman' realm founded by William the Conqueror in $1066 .{ }^{1}$ This proved one of the turning points in European history, establishing the Capetian monarchy as the dominant power in Western Europe. The separation of Normandy from England had more immediate implications for landed society in the two countries, as the insistence of both Philip and King John of England that landowners had to swear exclusive homage to one or the other of them effectively forced landowners with estates on both sides of the Channel to choose between their English and Norman properties. This fractured the Anglo-Norman political community, and the failure of repeated attempts by John and his son Henry III to recover Normandy and the other lost provinces ensured that this division would prove permanent. The break-up of cross-channel landholding also resulted in a significant redistribution of landed property in both England and France. In England, terre Normannorum ('the land of the Normans') formed 'the great bank on which the thirteenth-century kings drew for patronage' and, in France, Philip used the confiscated estates in Normandy to strengthen royal authority. ${ }^{2}$ The reactions of the Anglo-Norman aristocracy to the changing situation have also been studied and Daniel Power, in particular, has revealed the impact of the separation of England and Normandy on individual families and the strategies adopted by some to try and maintain their holdings in both countries. ${ }^{3}$ Finally, a number of studies have investigated the histories of certain estates after $1204 .^{4}$ Given this acknowledgement of the importance of the loss of Normandy and terre Normannorum for international, national and local history, it is perhaps surprising how little is known about the actual process and mechanics of the seizure of these estates.

\footnotetext{
* This article is based on research undertaken as part of the AHRC-funded research project, 'The "Lands of the Normans" in England, 1204-44' (http://www.hrionline.ac.uk/normans), based at the Humanities Research Institute, University of Sheffield. I am grateful to Daniel Power, the project director, for all his help and encouragement, as well to as the other members of the project team, Edmund Mackenzie, Jamie McLaughlin and Katherine Rogers. My time in Sheffield was also enlivened greatly by the company of Alan Bryson, Jeff Denton and Joy Lloyd. Finally, I must thank Adrian Bell and Christine Carpenter, together with the journal reviewers, for their comments on earlier versions of this article, and André Mansi, of the ICMA Centre at the University of Reading, and Paul Coles, of Cartographic Services at the University of Sheffield, for their assistance with the maps.

${ }^{1}$ The basic studies in English are F.M. Powicke, The Loss of Normandy, 1189-1204: Studies in the History of the Angevin Empire (2 ${ }^{\text {nd }}$ ed., Manchester, 1961); and W.B. Stevenson, 'England and Normandy, 1204-59' (2 vols., Univ. of Leeds Ph.D. thesis, 1974). For the latest research, see A.-M. Flambard Héricher and V. Gazeau, eds., 1204: La Normandie entre Plantagenêts et Capétiens (Caen, 2007).

${ }^{2}$ The quotation is taken from D.A. Carpenter, 'Roger Mortimer in the Period of Baronial Reform', A.J. Duggan, ed., Nobles and Nobility in Medieval Europe (Woodbridge, 2000), 188. L. Musset, 'Quelques Problèmes de l'Annexation de la Normandie au Domaine Royal Français', R.-H. Bautier, ed., La France de Philippe Auguste: le Temps des Mutations (Paris, 1982), 291-307; M. Nortier, 'Un Rôle des Biens Tombés en la Main du Roi en la Baillie de Lisieux après la Conquête de la Normandie par Philippe Auguste', Annales de Normandie, xlv (1995), 55-68; and D.J. Power, The Norman Frontier in the Twelfth and Early Thirteenth Centuries (Cambridge, 2004), 447-53.

${ }^{3}$ D.J. Power, 'The French Interests of the Marshal Earls of Striguil and Pembroke, 1189-1234', AngloNorman Studies, xxv (2003), 199-224; idem., “"Terra Regis Anglie et Terra Normannorum Sibi Invicem Adversantur": les Héritages Anglo-Normands entre 1204 et 1244', V. Gazeau and M. Bouet, eds., La Normandie et l'Angleterre au Moyen Âge (Turnhout and Paris, 2003), 189-208.

${ }^{4}$ Two particularly valuable examples are: D. Crook, 'The "Lands of the Normans" in Thirteenth Century Nottinghamshire: Bingham and Wheatley', Transactions of the Thoroton Society of Nottinghamshire, cviii (2004), 101-7; and N.C. Vincent, 'Twyford under the Bretons 1066-1250', Nottingham Mediaeval Studies, xli (1997), 80-99.
} 
This article will attempt to remedy this through a detailed examination of the most important surviving source for the properties in England seized in 1204, the 'roll of the values of the lands of the Normans started in the sixth year of the reign of King John' (Rotulus de valore terrarum Normannorum inceptus anno regni Regis Johannis sexto - hereafter RVTN). ${ }^{5}$ Our new knowledge of this crucial source will then be used to illuminate the process of seizure itself and the subsequent management of the properties involved.

As its title suggests, the RVTN is a roll containing valuations of properties seized into the hands of the English king after the loss of Normandy. It consists of four membranes, sewn head to tail in Chancery fashion. The membranes are numbered in reverse order, so that the first membrane as unrolled (and therefore the last membrane to have been written) is numbered membrane one and the first membrane as written is numbered membrane four. To avoid confusion, this article will follow the membrane numbers given in the manuscript. All four membranes are of roughly the same width, but membranes four, three and two are significantly longer than membrane one. ${ }^{6}$ This is significant, and this article will argue that the valuations entered on the lower half of membrane two and continued on membrane one represent a distinct stage in the compilation of the roll. There is a small amount of endorsed material on membranes three and two. The roll is written in more than one hand, although the workings of the chancery during the thirteenth century are obscure and it has not been possible to identify the responsible scribes. ${ }^{7}$ The $R V T N$ contains 114 separate entries, which give details of properties in 118 places seized from seventy-one different tenants, sixty lay and eleven ecclesiastical. The valuations are organised by county, as indicated by marginal notations. Furthermore, pairs of counties that shared a sheriff were entered either together or in sequence. ${ }^{8}$ The contents of the roll are summarised, and the people and places involved are identified, in the appendix, and the distribution of the properties appearing in the RVTN is shown on map one.

The first point to note is that the RVTN does not cover the whole of England. There are entries from either nineteen or twenty counties, just over half the total. ${ }^{9}$ As a result, the $R V T N$ certainly includes only a portion of the total number of estates seized. The vital question of the comprehensiveness of the RVTN as a record of terre Normannorum will be considered later. The coverage of the RVTN clearly favours central and southern England over the north, but there is no obvious reason for the

\footnotetext{
${ }^{5}$ The roll has been edited and published by the Record Commission (T.D. Hardy, ed., R[otuli] N[ormannice in Turri Londonensi Asservati] (London, 1835), 122-143). The original manuscript has also been consulted (T[he] N[ational] A[rchives], P[ublic] R[ecord] O[ffice], C 64/7).

${ }^{6}$ Membrane four is $750 \mathrm{~mm}$ long by $267 \mathrm{~mm}$ wide; membrane three is $600 \mathrm{~mm}$ by $263 \mathrm{~mm}$; membrane two is $700 \mathrm{~mm}$ by $269 \mathrm{~mm}$; and membrane one is $410 \mathrm{~mm}$ by $261 \mathrm{~mm}$.

${ }^{7}$ N.C. Vincent, 'Why 1199 ? Bureaucracy and Enrolment under John and his Contemporaries', A. Jobson, ed., English Government in the Thirteenth Century (Woodbridge, 2004), 39. More recently, each entry has been given an arabic number in pencil in the margin, running sequentially from one for the first entry on membrane four to the end of the roll. This numeration is not mentioned in the Record Commission edition of 1835 and may postdate it. The author and purpose of these annotations is unclear and they have no obvious relevance to the subject of this article.

${ }^{8}$ Although Surrey (included) and Sussex (excluded) were frequently held together, in 1204 the two had different sheriffs (respectively Robert of Thurnham and William Marshal, earl of Pembroke).

Nottinghamshire was also held with Derbyshire at this time, but there were no royal orders concerning terre Normannorum in the latter county during the period when the roll was compiled and thus no entries from Derbyshire appear in the RVTN.

${ }^{9}$ The total number of counties is uncertain because it is unclear whether the entry concerning the lands of Henry de Ferrières refers to Lechlade and Longborough in Gloucestershire, or to Oakham in Rutland, or indeed to all three places.
} 
Map 1. The distribution of estates in England referred to in the $R V T N$.

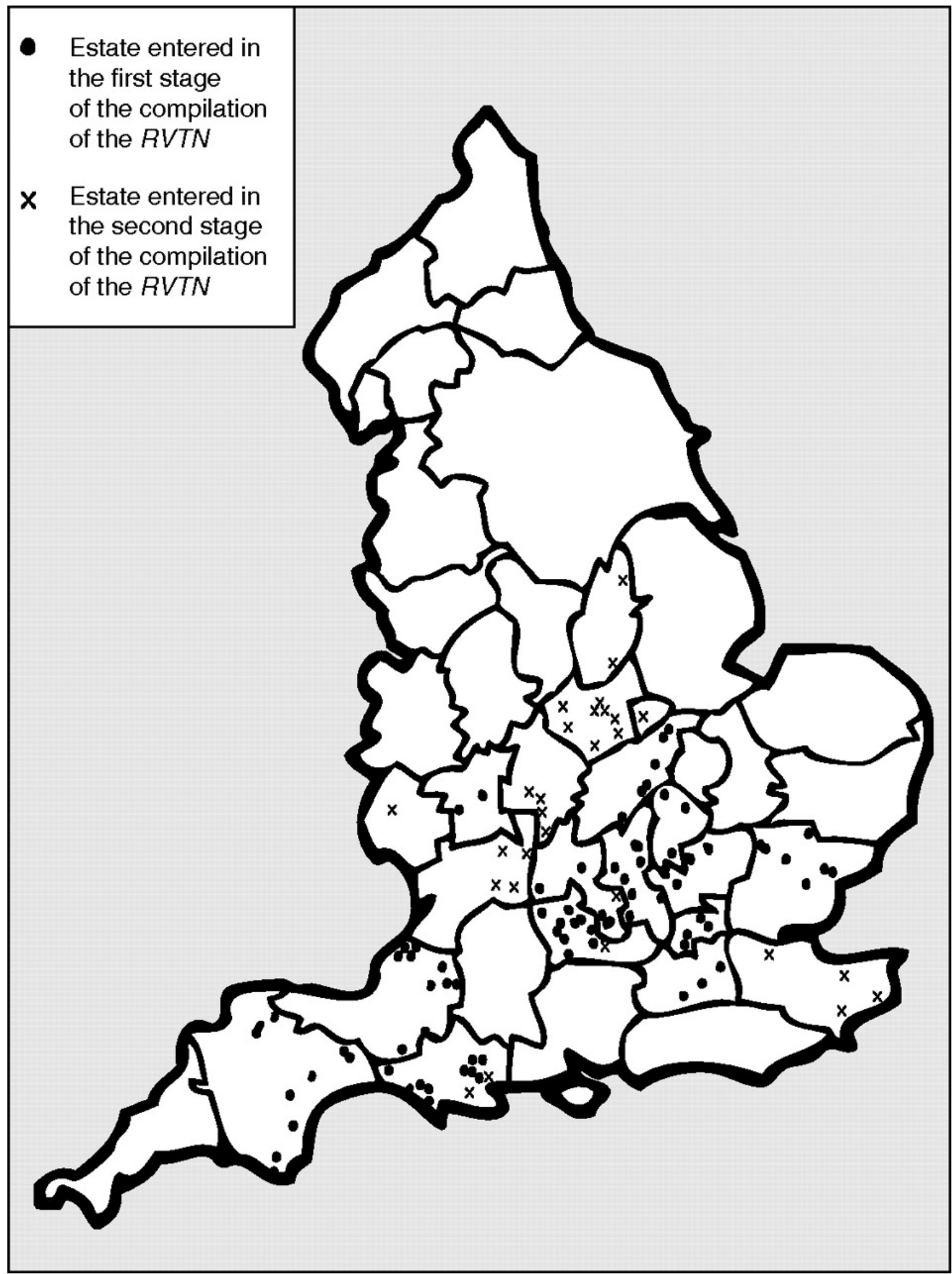


inclusion of some counties and the omission of others. The northern counties may have been excluded entirely, but so was East Anglia and there are also gaps in the coverage of southern England. Furthermore, there seems to be no geographical reason for the order in which the counties appear in the roll. David Crook has observed that Nottinghamshire is the most northerly county to be included, but the order of entry does not follow a south-north progression and it does not necessarily follow that the compilers were interrupted before they could continue further north. ${ }^{10}$ Moreover, where we can assign a more precise date to the valuations, there also seems to be no chronological order, either between counties or within the returns from any one county. Equally importantly, there is substantial uniformity in format within the returns from each county but differences in phrasing and subject matter between returns from different counties. These variations may reflect differing practices in the recording of these valuations from county to county and strongly suggest that the $R V T N$ is a compilation made centrally of valuations taken locally.

The first task is to estimate a date range for the compilation of the RVTN. The title of the roll states that it was begun in the sixth year of John's reign (3 June 1204-18 May 1205). Maurice Powicke suggested that the roll was written in or after October 1204, based on the statement that Henry of Sandwich was holding Bilsington (Kent), which was only granted to him on 30 September. ${ }^{11}$ This must be correct, so far as it goes, but it could also be misleading. The preceding two entries in the roll describe the lands late of Ralph Taisson in Patrixbourne and River (also Kent) as being in the keeping of Robert de Vieuxpont, but Vieuxpont had been ordered to deliver these manors to Reginald of Cornhill on 14 September. ${ }^{12}$ If the whole roll was compiled in October 1204, why was Vieuxpont rather than Cornhill described as holding these properties? There are numerous further examples where the property in question had changed hands during the summer of 1204 without these changes being recorded in the roll. In fact, it is clear that the valuations contained in the $R V T N$ were taken at a variety of different times between June and October 1204. Some entries must date from early summer, since they refer to the feast of the Nativity of St. John [24 June] as being in the future, while others must date from the autumn, since they describe the crops as having been harvested. ${ }^{13}$ The most convincing explanation for these apparent contradictions is that the compilers had gathered a series of valuations taken at different times, ordered them according to county and then entered them into the roll.

An initial hypothesis might be that the whole roll was compiled from these various records at some time after October 1204. On closer inspection, however, it is possible to distinguish between two distinct stages in the composition of the RVTN. The first was the transcription of a series of valuations datable to June 1204 and possibly taken before royal justices. This is the larger of the two sections of the RVTN, occupying the whole of membranes four and three and the first twothirds of membrane two. It includes seventy-nine of the 114 entries, starting with the two entries for Worcestershire and ending with the returns from Berkshire. It will be shown that it is possible to narrow the compilation of this first stage of the $R V T N$ down further and suggest that these valuations were entered into the roll between the first and third weeks of July 1204. The second was the recording of valuations taken in response to specific royal letters issued between August and the end of October 1204. These occupy the last third of membrane two and the whole of membrane one and were probably entered after the end of October. This can be demonstrated from a comparison

\footnotetext{
${ }^{10}$ Crook, 'The "Lands of the Normans" in Thirteenth-Century Nottinghamshire', 101.

${ }^{11}$ Powicke, Loss of Normandy, 288 n.42.

${ }^{12}$ T.D. Hardy, ed., R[otuli] L[itterarum] C[lausarum in Turri Londinensi Asservati] (2 vols., London, 183344), i, 10.

${ }^{13} R N, 135,140$.
} 
between the RVTN and the royal orders issued by the Chancery relating to the seized estates. Of the first seventy-nine entries in the RVTN, which have been assigned to the earlier stage of the roll's compilation, only four can possibly be linked to royal letters ordering the valuation of the property concerned. ${ }^{14}$ Of the valuations assigned to the second stage of compilation, by contrast, all but a handful can be linked to royal orders for the disposition and valuation of the properties concerned. ${ }^{15}$ This distinction is vital for our understanding of the RVTN, and this article will now examine the two stages of the compilation in more detail.

The valuations contained in the first stage of the compilation of the RVTN can be dated to June 1204 from internal evidence. The RVTN records that no return was made for the manors of Sturminster Marshall or Frampton (both Dorset) because they had been delivered to the countess of Meulan and the priory of Frampton respectively. ${ }^{16}$ The royal order to put the countess in seisin of Sturminster must have been issued before the octaves of Trinity (24 June), while the fine by the priory of Frampton to have the keeping of the lands of their parent house of Saint-Étienne, Caen, can be dated to around 14 June $1204 .{ }^{17}$ These provide an earliest possible date for the valuations contained in this stage of the RVTN's compilation. We can also assign a latest possible date of 24 June, as the valuation of the manor of Woolley in Chaddleworth (Berks.) refers to rents due at the feast of [the Nativity of] St. John coming. ${ }^{18}$ The most reasonable conclusion, therefore, is that the bulk of the valuations contained in the first section of the RVTN were taken around mid-June 1204.

It is also possible to suggest a likely date range for the writing of the first stage of the roll, based on the appearances of RVTN properties in other documentary sources. For instance, the entry for Newbury (Berks.) does not mention any royal custodian and the appointment of Simon of Pattishall as keeper of that manor was noted on the dorse of the second membrane, suggesting that he had not yet been appointed when the valuation was taken or when it was entered into the roll. ${ }^{19}$ Pattishall first appears in connection with Newbury on 23 July, although his appointment may precede this.

\footnotetext{
${ }^{14}$ Newton St. Loe (Soms.), Sturminster Marshall (Dorset), Mears Ashby (Northants.) and Wilden (Beds.) ( $R L C, \mathrm{i}, 4,6,11,12)$. These orders seem to postdate the completion of the first stage of the compilation of the $R V T N$. The example of Sturminster Marshall is perhaps the most illuminating. This manor appears on membrane four, where it was simply noted that it had not been valued because it was in the hand of the countess of Meulan by royal order. The full valuation of Sturminster entered at the end of membrane one can be linked to the grant of the manor to William Marshal on 9 September. The fact that this valuation was entered at the very end of the document rather than superseding the earlier entry demonstrates that it must have post-dated the first stage of compilation of the $R V T N$.

${ }^{15}$ The earliest surviving royal orders relating to three entries, namely Ilston-on-the-Hill, Rothley and Dartford, date from early 1205 ( $R L C, \mathrm{i}, 18,23)$. The valuations for Great Delce and River may have been taken at the same time as other properties held by the same tenants were valued (ibid., i, 5, 9), and those concerning Ashby-de-la-Zouche and the lands late of Henry de Ferrières may have been associated with fines to recover those properties made in the summer and autumn of $1204(R O F, 209,221)$.

${ }^{16} R N, 126$.

${ }^{17}$ C [uria] R[egis] R[olls, Richard I-Henry III] (20 vols., London and Woodbridge, 1922-2006), iii, 124; T.D. Hardy, ed., R[otuli de] O[blatis et] F[inibus in Turri Londinensi Asservati, Tempore Johannis] (London, 1835), 199-200. The prior of Frampton's fine was entered into the roll shortly before fines made by Fulk d'Oyry and John de Grey, bishop of Norwich. The latter two fines can be linked to a royal charter issued in favour of d'Oyry on 14 June (T.D. Hardy, ed., Rot[uli] Chart[arum in Turri Londinensi Asservati, 11991216] (London, 1837), 134-5) and a letter patent ordering the release of William Rigaud, knight of the bishop of Norwich, of 15 June (T.D. Hardy, ed., R[otuli] L[itterarum] P[atentium in Turri Londinensi Asservati] (London, 1835), 43).

${ }^{18} R N, 135$.

${ }^{19}$ Ibid., 142.
} 
Another endorsed note records the grant of Shilton (Berks.) to Beaulieu Abbey, made on 28 July. ${ }^{20}$ These are the only two such examples from the RVTN. The restoration of Easthorpe and Great Birch (Essex) to William Blund and the grant of Newton St. Loe (Soms.) to William le Gros, both on 3 August, were not noted in the RVTN, and neither was the recovery of the lands of Luke fitzJohn by his wife Eustacia on 15 August. ${ }^{21}$ Furthermore when orders were issued concerning additional terre Normannorum in these counties, such as the grant of the keeping of the lands of William Martel in Dorset and Somerset to William Marshal on 9 September, the $R V T N$ was not updated. ${ }^{22}$ It can therefore be concluded that the valuations contained in the first stage of the compilation had been entered into the RVTN by 23 July, that the roll was finalised between 28 July and 2 August and thereafter no new information concerning these properties or counties was added.

The content of the entries contained within the first stage of the compilation of the RVTN can also shed some light on how these valuations were reached. They seem to have been taken before royal justices, appointed to inquire into the properties seized and to hear the testimony of jurors as to the values of those properties. The $R V T N$ itself refers to these justices on two occasions. The entry concerning the land that Gilbert Malesmains formerly held in Great Gaddesden (Herts.) by right of his wife, Eleanor de Vitré, countess of Salisbury, records that the land was in the keeping of Geoffrey fitzPeter and that the four men and the reeve of the vill did not come before the king's justices to state how much the land was worth with stock and how much without stock. ${ }^{23}$ It may not be too cynical to suggest some connection between the non-appearance of the jurors and the fact that the land was in the keeping of fitzPeter, then justiciar of England. Likewise in Middlesex the four men and reeve did not come before the king's justices to testify as to the value of the lands of Gilbert Malesmains or Thomas de St-Valéry. ${ }^{24}$ Beyond these brief comments, there is very little evidence about the activities of these justices and no information about their composition or organisation. There were no itinerant justices active in 1204 and, although John heard pleas coram Rege during the spring and summer, the movements of the king's court do not coincide with the geographical coverage of the $R V T N .^{25}$ As a result, it is not known whether there was a panel of royal justices travelling from county to county, as during the visitations of the general eyre or the inquiry into wards and widows in 1185, or whether individual panels of local landowners were commissioned in each county, as for the inquiry into the lands of Montfortian rebels in $1265 .{ }^{26}$ There is a later mention of 'the justices appointed to hear accounts of the lands of the Normans' but, although tempting, there is no conclusive evidence identifying these justices with those before whom the valuations of June 1204 were taken. ${ }^{27}$

${ }^{20} R L C, \mathrm{i}, 3$.

${ }^{21}$ Rot. Chart., 135; RLC, i, 5.

${ }^{22}$ Ibid., i, 8. The exception of Sturminster Marshall discussed above may be taken as proving the rule.

${ }^{23} R N, 129$.

${ }^{24}$ Ibid., 130. These lands may have been in the keeping of fitzPeter and Hubert Walter, the royal chancellor and archbishop of Canterbury, respectively; fitzPeter was holding the Malesmains lands in Hertfordshire, and so it is at least possible that he was also holding the Malesmains lands in the neighbouring county of Middlesex, while Hubert Walter had come to an arrangement with Thomas de St-Valéry whereby he held the St-Valéry lands in Oxfordshire at farm of Henry de St-Valéry, Thomas' brother $(R L C, \mathrm{i}, 43)$.

${ }^{25}$ D.M. Stenton, ed., The Great Roll of the Pipe [for the Sixth Year of the Reign of King John, Michaelmas] 1204, Pipe Roll Society, 1 (1940), xi; D. Crook, Records of the General Eyre (London, 1982), 63, 68.

${ }^{26}$ For a discussion of the varieties of royal inquiries, see H.M. Cam, The Hundred and the Hundred Rolls (London, 1930), 27-32.

${ }^{27} R L C, \mathrm{i}, 19$. 
The second stage of the compilation of the RVTN starts with the entries for Warwickshire and coincides with a change of scribe mid-way through the third membrane, and contains valuations taken between August and the end of October 1204. In general, these entries provide similar information to those from the first stage of compilation. Rather than resulting from the investigation of a panel of justices, however, these valuations were returns to a series of royal letters close concerning individual seized properties, usually as part of the commission of that property to a new holder. It will be shown that John only made such grants at pleasure and often required the new holder to answer for the issues of the land at the Exchequer. As a result, the royal government needed to know how much these properties were worth. Most of these royal orders therefore contained a clause to value the land at its greatest extent, in the same way as the king's own manors ought to be valued. ${ }^{28}$ Moreover, and unlike most of the returns from the first stage of compilation, there is no mention of the statements of jurors or of the names of any keepers of the property. This hypothesis can best be proved through the collation of the RVTN entries with royal orders concerning terre Normannorum in those same counties, mostly recorded in the close rolls.

This process can be illustrated using the first group of entries from the second stage of the RVTN, namely those relating to Warwickshire. They form a group with a distinctive format; the valuations are introduced with the phrase 'the same manor is worth' and begin with a statement of the value of the rent of assize before giving an assessed value if the property were fully stocked. ${ }^{29}$ These can be linked to a series of royal grants of terre Normannorum in Warwickshire during August, September and October 1204. The first valuation to be taken was probably that concerning Atherstone, even though it was only the third of the four Warwickshire properties to be entered into the RVTN. A letter close of 3 August ordered the sheriff of Warwickshire to value the land late of William [recte Ralph] de Rupierre in Atherstone, and then to deliver that land to the Templars, who were to answer therefor at the Exchequer. This must have been returned by 20 August, when a second letter close confirmed the grant of Atherstone to the Templars at a farm of $£ 4$ per annum, the same value as given in the $R V T N .^{30}$ Of the other Warwickshire estates, Whichford was granted to Reginald de Moyon on 21 September and Aston Cantlow, of which Wilmcote was a sub-manor, was granted to William de Cantiloupe on 22 September. Finally, on 14 October, the king assigned land in Ilmington to Owain ap Dafydd. ${ }^{31}$ These are the only four letters close recorded from this period to concern terre Normannorum in Warwickshire.

Although some conclusions can be reached about how and when the RVTN was compiled, it is still not immediately apparent what the purpose of the roll actually was. In particular, there are only a handful of examples of the valuations contained in the $R V T N$ being used in other administrative documents. For instance, Richard Fleming made fine to have $£ 4$ land in Holditch in Thorncombe and Robert de Secqueville to have land worth $£ 7$ in Dunsford and 60s in Rewe (all Devon). In both cases the values placed on these lands in the fines correspond to the valuations made in $1204 .{ }^{32}$ Of

\footnotetext{
28 extendi faciatis... ad plus quod poterit extendi secundum quod maneria nostra extendi solet. The earliest use of this phrase is in a writ of 2 August (ibid., i, 4).

${ }^{29} R N, 138-9$.

${ }^{30} R L C, \mathrm{i}, 5,6$.

${ }^{31}$ Ibid., i, 10, 12.

${ }^{32} R O F, 217,221 ; R N, 130$. These fines can be dated to around September 1204 from their position in the roll. Other similar examples concern West Alvington (Devon) and Duddington (Northants.) ( $R L C, \mathrm{i}, 12,28 ; R N$, $130,134)$. Finally, the extent of Newbury (Berks.) in the $R V T N$ records that the farmer of the manor owed a customary payment of $£ 81 \mathrm{~m}$ to the priory of Sandford. A royal letter of 23 July ordered Simon de Pattishall, then keeper of the manor, to pay an equivalent sum to the prior $(R L C, \mathrm{i}, 3)$. It is even possible that it was the entry of the extent of Newbury into the RVTN that reminded the royal clerks to arrange for this payment to be
} 
course, it is possible that the valuations referred to in these fines were taken directly from the rolls of the justices or the returns of the sheriffs on which the RVTN itself was based. Conversely, there are a number of inconsistencies between values as reported in the RVTN and in other sources. A letter close of 19 September states that the king had been informed that Robert de Thibouville's land of Grendon Underwood (Bucks.) was worth 100s per annum, whereas in the RVTN it is valued at $£ 6 .{ }^{33}$ Again, Eustacia de Courtenay was to answer for a farm of $£ 15$ per annum for the lands that her husband Luke fitzJohn had held on the day that he left the king's service, lands which were mostly of her inheritance, but the valuation in the RVTN, which does not include all of fitzJohn's former properties, suggests a minimum value of over $£ 38$ for his estates. ${ }^{34}$ Furthermore, on 3 August the king granted Newton St. Loe (Soms.) to William le Gros, presumably the same man whose behaviour while steward of Normandy in 1203-4 had so alienated local landholders. This letter close stated that if the land had not already been taken into the king's hands, then the sheriff was to do so, and also to value the land and inform the king of its value. ${ }^{35}$ Newton St. Loe had already been valued, and this would suggest that the $R V T N$ was not regularly consulted before the king made grants of terre Normannorum.

In fact, while the style of enrolment suggests that it was probably compiled at the Chancery, the $R V T N$ may have been produced either for the Exchequer or for a special body of justices appointed to oversee the management of the seized estates. It is noticeable that the entry of new items ends in late October, at precisely the time when the close roll for the first half of John's sixth regnal year was sent to the Exchequer. ${ }^{36}$ The most plausible hypothesis is that the roll was compiled as a backup record of the valuations of terre Normannorum properties, abstracted from the returns taken before justices in June and from the sheriffs' returns in response to royal letters from August 1204, and possibly intended for use in auditing the accounts presented by the sheriffs or keepers of these manors. Significantly, these accounts were not enrolled on the main Pipe Roll but entered on a separate roll. In 1204 the surplus of the sheriff of Dorset and Somerset in his county account was allowed against an outstanding sum in 'the account roll for the lands of the Normans', and in 1205 the sheriff of Nottinghamshire and Derbyshire was credited 'in the account for the lands of the Normans' ${ }^{37}$ Furthermore, there is a reference in February 1205 to 'the justices appointed to hear accounts of the Lands of the Normans'. ${ }^{38}$ There are no more references to these account rolls or these justices after 1205. Unfortunately, these account rolls do not survive, which is a great loss for

made.

${ }^{33}$ Ibid., i, 10 .

${ }^{34} R N, 130,133$. Eustacia had made fine by $15 \mathrm{~m}$ for this grant ( $\left.R O F, 212-13\right)$. This fine can be dated to circa 15 August, since on that day the king issued letters close to the sheriffs of Devon and Surrey and Sussex ordering them to put her in seisin of these lands $(R L C, \mathrm{i}, 5)$. According to the Pipe Roll of 1205, she was supposed to account for a farm of $£ 15$ pa, but paid nothing (S. Smith, ed., The Great Roll of the Pipe [for the Seventh Year of the Reign of King John, Michaelmas] 1205, Pipe Roll Society, li (1941), 23).

${ }^{35} R L C$, i, 4. Le Gros' misdeeds in Normandy were still remembered in 1247 (D.J. Power, 'King John and the Norman Aristocracy', S.D. Church, ed., King John: New Interpretations (Woodbridge, 1999), 132-4). For more details on the family, see N.C. Vincent, 'The Borough of Chipping Sodbury and the Fat Men of France', Transactions of the Bristol and Gloucestershire Archaeological Society, cxvi (1998), 144-8.

${ }^{36}$ The close roll is annotated hinc mittendum ad scaccarium after the entries from 26 October and before those from 27 October $(R L C, \mathrm{i}, 13)$.

${ }^{37}$ in compoto rotuli de terris Normannorum (Great Roll of the Pipe 1204, 186); and in compoto de terris Normannorum (Great Roll of the Pipe 1205, 221). These rolls cannot be identified with the RVTN itself, which is not an account but a record of the valuations of properties, although it may have served as a basis for account.

${ }^{38} R L C$, i, 19. 
our understanding of the scale of the seizure and the initial management of the seized estates. It is possible that, after the relevant details had been extracted from the RVTN and entered into this account roll or rolls, the RVTN was considered to have served its purpose and the clerks ceased to update it.

While it may have outlived its contemporary usefulness, the RVTN remains a key historical source, particularly as there is a notable lacuna in the surviving evidence for the vital period immediately before the loss of Normandy. Most administrative orders to local officials, including those regarding the seizure and distribution of terre Normannorum estates, were sent as letters close. Unfortunately, the close roll for the fifth year of John's reign (ending on 2 June 1204) does not survive and it is likely that any writs ordering a general seizure of terre Normannorum would have been entered into this lost roll. The close roll for the sixth year is still extant, but there is a marked lack of entries relating to terre Normannorum before late July 1204, coinciding neatly with the period when the first section of the RVTN was being compiled. ${ }^{39}$ Likewise the fine roll for the fifth year of the reign is missing, although that for the sixth year does survive. In addition, although the patent and charter rolls for both the fifth and sixth regnal years all survive, there seem to have been few letters patent or charters issued during the key period of May and June 1204 and, moreover, none of these involved terre Normannorum. ${ }^{40}$ There is a wider significance to the fact that John did not use royal charters when making grants of the seized properties, as will become clear later.

As a result, the actual document by which John ordered the seizure of the lands of those landowners who had remained in Normandy does not survive, either in the original or as a copy. Since the text of the original royal order is not known, it is necessary to deduce the nature of that order from references and phrases used in later sources, as well as via an analysis of the people and properties involved. An early fine refers to land seized 'on account of the Normans' or, alternatively, the dispossessed tenant could be described as having 'left the service of the lord king', or as being 'with the king's enemies'. ${ }^{41}$ The latter, however, was a standard form of words and not unique to the seizure of 1204. For example, it was used in a writ of 1 May 1204, predating the final French campaign in Normandy, relating to Nettlestead (Suffolk) and the lands of Geoffrey fitzHaimo 'who is in Brittany with the king's enemies'. This same writ also includes clauses to value and extend the land in similar words to those used in the orders described above. ${ }^{42}$ The best evidence of the order of 1204 itself can be found in fines that refer to 'the royal order that the Normans were to be disseised of their lands' or 'the general order concerning the lands of the Normans'. Unfortunately, neither of these phrases provides any specific information about the process or even the date of the seizure.

\footnotetext{
${ }^{39}$ There are only three references to terre Normannorum between 3 June and 20 July (ibid., i, 1-3).

${ }^{40}$ There are no letters patent recorded from the crucial period between 10 May and 4 June $(R L P, 42-3)$ and no royal charters between 18 May and 14 June. Moreover, there were only six charters issued between 14 June and 3 August (Rot. Chart., 133-5).

${ }^{41}$ For the phrase occasione Normannorum, see $R O F, 204,221,228$. The latter two phrases are both used in a plea heard during Easter term 1206, which mentions Alan Martel, qui fuit contra dominum rege cum inimicis domini regis, and also refers to omnium Normannorum qui recesserunt de servicio domini regis (CRR, iv, 101-2). Similar formulations can be found in a number of fines made during the summer and autumn of 1204 (ROF, 211-12, 223, 238-9).

${ }^{42}$ T.D. Hardy, ed., Rot[uli de] Lib[erate ac de Misis et Praestitis, Regnante Johanne] (London, 1844$), 95$. ${ }^{43}$ ROF, 230, 334.
} 
Another important clue about the nature of the seizure of 1204 can be found in a plea heard before the royal courts in 1231 , nearly three decades later. ${ }^{44}$ The king, represented by the justice William le Breton, had claimed the manor of Duddington (Northants.) as his escheat of 'the lands of the Normans' and, in response, the current tenants Oliver d'Aincurt and Nicola his wife called William II Longespée and his wife Idonea to warrant their possession. Idonea was the grand-daughter and heiress of Nicola de la Haye, who had received Duddington (and land in nearby Easton-on-the-Hill) as part of her share of the barony of La Haye-du-Puits. One of the other co-heirs to La Haye-duPuits was Richard II du Hommet, son of the constable of Normandy. Richard died before 1204, but Duddington seems to have been taken into the king's hands along with the other Hommet properties as part of the general seizure. ${ }^{45}$ On 4 June the king had ordered Duddington and Easton-on-the-Hill to be restored to Gerard de Canville (Nicola's second husband), which lands Canville had held of the fee of the constable of Normandy. ${ }^{46}$ In his reply to Breton's claim that Duddington had been confiscated as terre Normannorum, Idonea's attorney argued that 'when the lord king took into his hand the lands of the Normans, he took that land in his hand only in simple seisin and, afterwards, when he had learned the truth, he restored that land to them'. ${ }^{47}$ The order of 1204 was therefore not for the ultimate confiscation or forfeiture of the lands of the Normans, but rather for the lands of people suspected of supporting the French king to be taken into royal possession pending investigation. For this reason, this article has been careful to refer to the seizure rather than the confiscation of terre Normannorum. Furthermore, as will be established later, a number of properties appearing in the $R V T N$ were quickly restored to their former holders once it had been established that they were not in the 'power' of the king of France.

It is possible to make some further inferences about this 'general order concerning the lands of the Normans'. It was probably addressed to the sheriffs, since the majority of subsequent orders concerning terre Normannorum were sent to the sheriff of the county in which the property lay. In a smaller number of cases, however, there is evidence that it may have been other royal officials that seized the property. The manors of Laughton-en-le-Morthen (Yorks.) and North Wheatley (Notts.), which were held of the honour of Tickhill, first appear in the keeping of the constable of Tickhill and it is likely that the constable seized these properties. ${ }^{48}$ It was William de la Falaise, keeper of the honour of Gloucester, then in the king's hands, who was ordered to restore the manor of Stambourne (Essex), which was held of that honour, to Gerard de Greinville. ${ }^{49}$ Another case is that of John d'Argentan, who complained that his property in Carisbrooke in the Isle of Wight, which he claimed to have acquired from Richard and Bernard de la Tour before they left the king's service,

\footnotetext{
${ }^{44}$ F.W. Maitland, ed., Bracton's Note Book [: a Collection of Cases Decided in the King's Courts During the Reign of Henry III, Annotated by a Lawyer of that Time, Seemingly Henry of Bratton], (3 vols., London, 1887), ii, 391-3, 437-8; CRR, xiv, 242-3, 254.

${ }^{45}$ The manor of Duddington held by Gerard and Nicola is not included in the RVTN, however, because it was restored to them on 4 June, that is, before the inquiries that make up the first stage of the RVTN were held. The property in Duddington that does appear in the RVTN represents a different estate, although in the same place, that had come to Fulk Paynel $(R N, 134)$. In 1205 this land was also granted to Gerard and Nicola, in compensation for the land in Easton-on-the-Hill, which they had lost when King John had granted it to Simon of Lindon, who had an ancestral claim to that land (RLC, i, 28; ROF, 199-200).

${ }^{46} R L C, \mathrm{i}, 1$.

${ }^{47}$ Bracton's Note Book, ii, 393. The translation is mine.

${ }^{48} R L C$, i, 10. The honour of Tickhill was in the keeping of Robert de Vieuxpont, but the constable of Tickhill was Odo de Crossby, and the RVTN records that Odo had collected $£ 238 \mathrm{~s} 4 \mathrm{~d}$ from the farm, men and stock of North Wheatley and was refusing to answer for this except before the king $(R N, 141)$.

${ }^{49} \mathrm{ROF}, 234$.
} 
had been seized by the constable of Carisbrooke castle. ${ }^{50}$ In this example, the constable of Carisbrooke was obviously better placed to take action regarding properties on the Isle of Wight than the sheriff of Hampshire, who was based on the mainland. More interesting is the apparently minor role played by private lords in seizing properties held of their fees. In those cases where the feudal lord later acquired the keeping of terre Normannorum held of his fee, it was the sheriffs who were ordered to deliver those properties to the lord.

Perhaps of greater relevance than the mechanics of the seizure process is the date on which this 'general order' was issued, and the surviving documentary records can be used to identify a rough date range. The sheriffs' accounts heard in Michaelmas 1204 generally record that Norman holders of terre date held for the first half of the Exchequer year, that is from Michaelmas 1203 until Easter 1204 (25 April). Examples include the lands of Robert d'Harcourt and his son John in Benson (Oxon.) and Rothley (Leics.) respectively, Ralph de Tilleul in Wendover (Bucks.), and Robert Bacon in Dartford (Kent). ${ }^{51}$ These dates are obvious approximations, and reflect the accounting conventions of the Exchequer, which generally rounded such allowances to the nearest half- or quarter-year, but they correspond closely to the chronology of the seizures, as known from other sources. ${ }^{52}$ Easter provides a terminus post quem for the seizure and, as will be seen, the order must have postdated Easter by some weeks. It is possible to be more confident about assigning a terminus ante quem, based on Chancery records. These show that the lands of the countess of Perche were in the king's hands by 3 June 1204 and those of William du Hommet by 4 June. The ecclesiastical rents of Amaury son of Robert d'Harcourt were granted to Peter des Roches between 4 and 6 June and the lands of John de Préaux and Ralph Taisson, two important Anglo-Norman lords, were in the king's hands by 13 June. ${ }^{53}$ Finally, as discussed above, the prior of Frampton made fine to have the keeping of the manor of Frampton, a possession of the abbey of St- Étienne of Caen, parent house of Frampton priory, around 14 June. The actual seizure of Frampton must have predated this by some time, since the prior must have had time to discuss the matter with his convent and to send a messenger to the king, then at Kingston or Merton.

The political context can also help to further refine the date range for the confiscation. The weakening position of the Plantagenets in Normandy had been demonstrated by the fall of Chateau Gaillard on 6 March 1204. ${ }^{54}$ In response, John dispatched a high-powered commission, led by Hubert Walter, archbishop of Canterbury, John de Grey, the chancellor and bishop of Norwich, and the Anglo-Norman magnates William Marshal, earl of Pembroke and Robert de Breteuil, earl of Leicester, further supported by the papal legate, the abbot of San Giovanni de Casamario, to negotiate with Philip Augustus. The envoys probably departed around 11-12 April and met Philip at around Easter (25 April). ${ }^{55}$ John is unlikely to have taken the drastic measure of ordering a general

\footnotetext{
${ }^{50}$ Ibid., 238-9. For Richard de la Tour, viscount and burgess of Argentan, and his brother Bernard, see Power, Norman frontier, 78; idem., 'L'Établissement du Regime Capétian en Normandie: Structures Royales et Reactions Aristocratiques', 1204: La Normandie entre Plantagenêts et Capétiens, 329.

${ }^{51}$ Great Roll of the Pipe 1204, 9, 106, 212, 220.

${ }^{52}$ Interestingly, the sheriff of Norfolk and Suffolk was allowed $£ 4518$ s for the terre date held by Geoffrey and Reginald de Bosco in Lothingland (Suffolk) during the first three-quarters of the year, that is until the feast of the Nativity of John the Baptist (24 June). This is significant, because Geoffrey was a member of the garrison of Rouen, which surrendered to Philip on that same day (ibid, 233; Powicke, Loss of Normandy, 261).

${ }^{53} R L C, \mathrm{i}, 1 ; R L P, 43$.

${ }^{54}$ Powicke, Loss of Normandy, 253-6.

55 The envoys received letters of protection on 8 April and Hubert Walter witnessed his last royal letter on 11 April (RLP, 40); for their meeting with Philip, see Radulphi de Coggeshall [Chronicon Anglicanum], J.
} 
confiscation of Norman lands before he had heard the result of this mission. In fact, as late as 15 May John seems to have been unaware of the sheer speed and scale of the débacle in Normandy, since on that day he sent orders to the steward of Normandy and constable of Rouen that assumed that he still controlled a sizeable chunk of the duchy. ${ }^{56}$ In the mean time, Philip had entered Normandy, rapidly over-running the duchy and taking the key town of Caen. John's state of blissful ignorance did not prevail for long. His envoys had returned to England by 18 May at the latest, no doubt bearing news of Philip's intention to press home his advantage, and they were closely followed by the records of the ducal administration, which were removed from Caen and had arrived back in England by 21 May. ${ }^{57}$ The general order for the confiscation can therefore be dated to sometime between 18 May and 2 June. Meanwhile, in Normandy, pockets of resistance at Rouen, Arques and Verneuil held out until late June. This is significant, because it means that the general order for the confiscation of terre Normannorum must have preceded the final collapse of Plantagenet power in Normandy.

A projected date of late May for the order also corresponds well with the chronology of the French campaign in Normandy. ${ }^{58}$ John probably expected Philip to fight his way east to west from Rouen to Caen and, accordingly, he had based his defence on the lines of the rivers Risle and Touques. ${ }^{59}$ These preparations were in vain, however, as Philip outmanoeuvred John by executing a 'left-hook' and bypassing these rivers to the south. ${ }^{60}$ The French entered Plantagenet-held Normandy on 2 May and reached Argentan on 7 May. Falaise, under the command of the mercenary Louvrecaire, was the next target and it surrendered after a one-week siege. This opened the route to Caen and the French forces probably reached the city shortly afterwards, possibly as early as 15 May. ${ }^{61}$ At the same time as Philip's army was advancing through central Normandy, the Bretons under Guy de Thouars had taken Mont-St-Michel and, ignoring for the moment the remaining Plantagenet-held castles along the Norman-Breton border, travelled via Avranches to join Philip at Caen. The possession of Caen was crucial. Although Rouen was the largest town in Normandy, Caen was the heart of the ducal administration and was located in the centre of the duchy. From the evidence of

Stephenson, ed., (London, 1875), 144.

${ }^{56} R N, 121$. John ordered William le Gros, steward of Normandy, and Peter de Préaux (presumably as constable of Rouen) to restore Hugh de Montfort to seisin of his lands in Normandy and to resume into the king's hands the lands that Hugh had previously received from the king in exchange. This writ was issued at Southampton on 15 May. Its significance does not seem to have been noticed before.

${ }^{57}$ One of the envoys, John de Grey, bishop of Norwich, witnessed a royal charter on 18 May (Rot. Chart., 132). The earls of Pembroke and Leicester remained in Normandy, and later met Philip at Lisieux. For the arrival of the ducal archives in England, see Rot. Lib., 102-3; RLC, i, 33.

${ }^{58}$ The following account has been reconstructed from the main chronicle sources (Radulphi de Coggeshall, 144-6; Eeuvres de Rigord et de Guillaume le Breton, H. Delaborde, ed. (2 vols., Paris, 1882-5), i, 160-1, ii, 210-17; Histoire des Ducs [de Normandie et des Rois d'Angleterre: Publiée en Entier, pour la Première Fois, d'après Deux Manuscrits de la Bibliothéque du Roi], F. Michel, ed. (Paris, 1840), 97-8) and Philip's acta (H. Delaborde et al, eds., Recueil des Actes de Philippe Auguste[, roi de France] (6 vols., Paris, 1916-2005), ii, 361-89). For other recent reconstructions, which come to broadly similar conclusions, see F. Neveux, 'Les Événements de 1204 dans leur Contexte Historique', 1204: La Normandie entre Plantagenêts et Capétiens, 17-19; and R. Robert-Barzman, 'La Conquête de la Normandie dans la Philippide de Guillaume le Breton', ibid., 179-83.

${ }^{59}$ Powicke, Loss of Normandy, 253.

${ }^{60}$ W. L. Warren, King John (2 ${ }^{\text {nd }}$ ed., London, 1978), p.97.

${ }^{61}$ François Neveux and Alain Leménorel have given a date of 21 May for the capture of Caen (Neveux, 'Les Événements de 1204', 17; Nouvelle Histoire de la Normandie: entre Terre et Mer, ed. A. Leménorel (Toulouse, 2004), 111), but it has not been possible to find any references to an precise date for the surrender of Caen or the arrival of the French and Breton forces there. 
the chronicles, it seems as though most other Norman towns and castles came to terms with Philip after the fall of Caen. The French king's next move was to divide his forces; the Bretons, with some of the French troops, moved south-west to mop up the last pockets of Plantagenet resistance on the Norman-Breton border, while Philip himself struck out towards Rouen. He passed via St-Pierre-surDives, Lisieux, Bonneville-sur-Touques and Pont-Audemer, arriving opposite Rouen on the western bank of the Seine by the end of May. The three fortresses of Rouen, Arques and Verneuil remained in Plantagenet hands, but when it became clear that they could expect no relief from John, the garrisons came to an agreement with Philip and surrendered on 24 June, thus completing the conquest of Normandy.

Around this time, most likely after taking Caen, Philip issued an ultimatum that those landholders who wished to retain their Norman properties should pay homage to him before Easter $1205 .{ }^{62}$ It is likely that many Anglo-Norman lordholders came to terms with the French king as a result. In general, the transition between Plantagenet and Capetian lordship for these men seems to have been remarkably smooth, and this must have contributed to the speed and completeness of the French conquest. At least one chronicler thought that the defection (described as treason) of William du Hommet, the constable of Normandy, was crucial to Philip's success. ${ }^{63}$ More concretely, John de Préaux was still in King John's service and favour on 31 March but by 1 June he was helping the French king to negotiate with the garrison of Rouen, which happened to be commanded by his brother, Peter. ${ }^{64}$ It is a significant guide to Philip's intentions that when agreement was reached with the garrison of Rouen on 1 June, he also advanced an amnesty to all Norman lords, only excepting three named men. ${ }^{65}$ Philip seems to have succeeded in his attempts to build bridges with the remaining Norman lords, and Daniel Power has shown that the Norman baronage of the second rank took a leading role in the duchy after $1204 .{ }^{66}$ It is notable that most of these men appear in the RVTN, including the families of Bertrand, Coulonces, Courcy, Ferrières, Harcourt, Hommet, Malet, Martel, Paynel, Tancarville and Taisson.

There are no surviving records of most of the agreements between the French king and individual Anglo-Norman landholders, but it is known that the earls of Pembroke and Leicester, members of the delegation sent by John who had subsequently remained in the duchy, met Philip at Lisieux, en route from Caen to Rouen, to bargain for more time before committing themselves. ${ }^{67}$ Furthermore it

\footnotetext{
${ }^{62}$ Recueil des Actes de Philippe Auguste, ii, 491-2; A.J. Holden, D. Crouch and S. Gregory, eds., History of William Marshall (3 vols., London, 2002-7), ii, 144-7. For a detailed argument setting out the date of this act, see C. Petit-Dutaillais, 'Études sur le "Registrum Veteris" et la Date de Quelques Actes de Philippe-Auguste', Bibliothèque de l'École des Chartes, xcix (1938), 59-63.

${ }^{63}$ H. R. Luard, ed., Annales Monastici (5 vols., London, 1864-9), ii, 255-6.

${ }^{64}$ Rot. Lib., 88; the agreement between Philip and the garrison of Rouen states that hostages were accepted ad laudem Johannis de Pratellis (Recueil des Actes de Philippe Auguste, ii, 381). This is discussed in Power, 'King John and the Norman Aristocracy', 134-5.

65 Those named were William le Gros, the steward of Normandy, Robert count of Meulan, and Roger de Tosny, as well as the Tosny's sons (Recueil des Actes de Philippe Auguste, ii, 380).

${ }^{66}$ Power, 'L'Établissement du Regime Capétian en Normandie', 328-32.

${ }^{67}$ History of William Marshal, ii, 144-7. The terms of Pembroke's agreement survive and, in addition to paying $500 \mathrm{~m}$, he also promised to hand over the keeping of his castles to Osbert de Rouvray, brother of John, a Norman knight who had defected to Philip (A. Teulet, ed., Layettes du trésor de Chartes (5 vols., Paris, 1863-1909), i, 250). For further discussion, see D.J. Power, 'French Interests of the Marshal Earls', 207-9; and for the de Rouvrays, see idem., 'Between the Angevin and Capetian Courts: John de Rouvray and the Knights of the Pays de Bray, 1180-1225', K.S.B. Keats-Rohan, ed., Family Trees and the Roots of Politics: the Prosopography of Britain and France from the Tenth to the Twelfth Century (Woodbridge, 1997), 363-82.
} 
can be suggested that, since it was the English estates of those Anglo-Norman landowners who came to terms with Philip that were confiscated by John, there should be a correlation between the progress of Philip's campaign through Normandy and the seizure of terre Normannorum in England. This can be seen on map two, showing the chief estates in Normandy of those AngloNorman landholders that appear in the RVTN, as well as the routes taken by the French and Breton forces. It is clear that the distribution of these estates closely matches the route taken by Philip and his army during his invasion of Normandy in May 1204, presumably reflecting the fact that landholders would have approached the French king as he passed through their localities.

The Norman estates of those landowners whose English properties were seized in 1204 were clustered in the Cotentin, the Bessin and the Pays d'Auge. These were regions of Normandy that had previously remained largely untouched by the growing French pressure. Daniel Power has stressed the extent to which the lords of central and north-western Normandy were unprepared for the sudden irruption of conflict in 1203 and 1204, unlike their fellows in the southern and eastern marches, who had become accustomed to the struggle between Plantagenet and Capetian. ${ }^{68}$ The counterpoint to the concentration of these properties in central and western Normandy is the absence of estates held in southern and eastern Normandy. This is not surprising since Philip Augustus had already occupied these areas in 1202 and 1203. Even before the start of the final campaign in May 1204, the French controlled Normandy east of a line drawn between Arques, Rouen and Verneuil and south of a line drawn from Mayenne through Alençon and Sées to Évreux. ${ }^{69}$ Those Anglo-Norman lords whose Norman lands lay in these regions had already had to choose between their English and Norman interests. Those who had chosen to retain their Norman estates had therefore already forfeited their lands in England. There are equally few properties lying in the Pays de Caux, between the rivers Seine and Béthune. This probably reflects the fact that this area was protected by the resistance of Arques and Rouen until the end of June, by which time the bulk of the RVTN had been compiled.

These conclusions about the French campaign and the dating of the order for confiscation can help to explain one of the central features of the RVTN, namely the omission of many notable Norman lords with lands in England. For example, the lands of Guy de Thouars, count of Brittany, and Juhel de Mayenne had been seized in 1202-3 and do not appear in the $R V T N .^{70}$ While most of the lands held by the counts of Brittany as lords of the honour of Richmond lay in counties not covered by the RVTN (namely Lincolnshire, Norfolk, Suffolk and Yorkshire), the valuable manor of Cheshunt in Hertfordshire, which county does appear in the RVTN, is not mentioned in the roll. ${ }^{71}$ Mayenne held Ringwood in Hampshire, not included in the RVTN, but he also held Black Torrington in Somerset and King's Nympton in Devon. Although the first stage of the RVTN contains valuations of properties from both these counties, neither manor is featured, presumably because they had already been seized into the king's hands and entrusted to the keeping of Geoffrey de Lucy. ${ }^{72}$ Other

For the truce granted to the earl of Leicester, see the Lire Chronicle in M. Bouquet et al, eds., Recueil des Historiens des Gaules et de la France (24 vols., Paris, 1738-1904), xviii, 352.

${ }^{68}$ Power, 'King John and the Norman Aristocracy', 122.

${ }^{69}$ For Philip's advances in 1202 and 1203, see Powicke, Loss of Normandy, 251-3; Power, Norman Frontier, 432-45.

${ }^{70}$ Ibid., 438, 441-2. For a detailed examination of the relationship between John and Juhel, see A. Renoux, 'Le Roi Jean, 'S'il Avait Capturé le Comte Robert d'Alençon et le Sire Juhel de Mayenne, il l'Aurait Gagnée sa Guerre” (1203)!', 1204: La Normandie entre Plantagenêts et Capétiens, 250-3.

${ }^{71}$ W. Page, ed., The Victoria History of the County of Hertford (4 vols., London, 1902-23), iii, 446.

${ }^{72} R L C, \mathrm{i}, 1$; in 1205 Ringwood was held by a royal household knight of German origin, Theodoric Teutonicus (or le Tyes), and Theodoric may have been in possession earlier (ibid., i, 50). 
Map 2. Normandy in May 1204

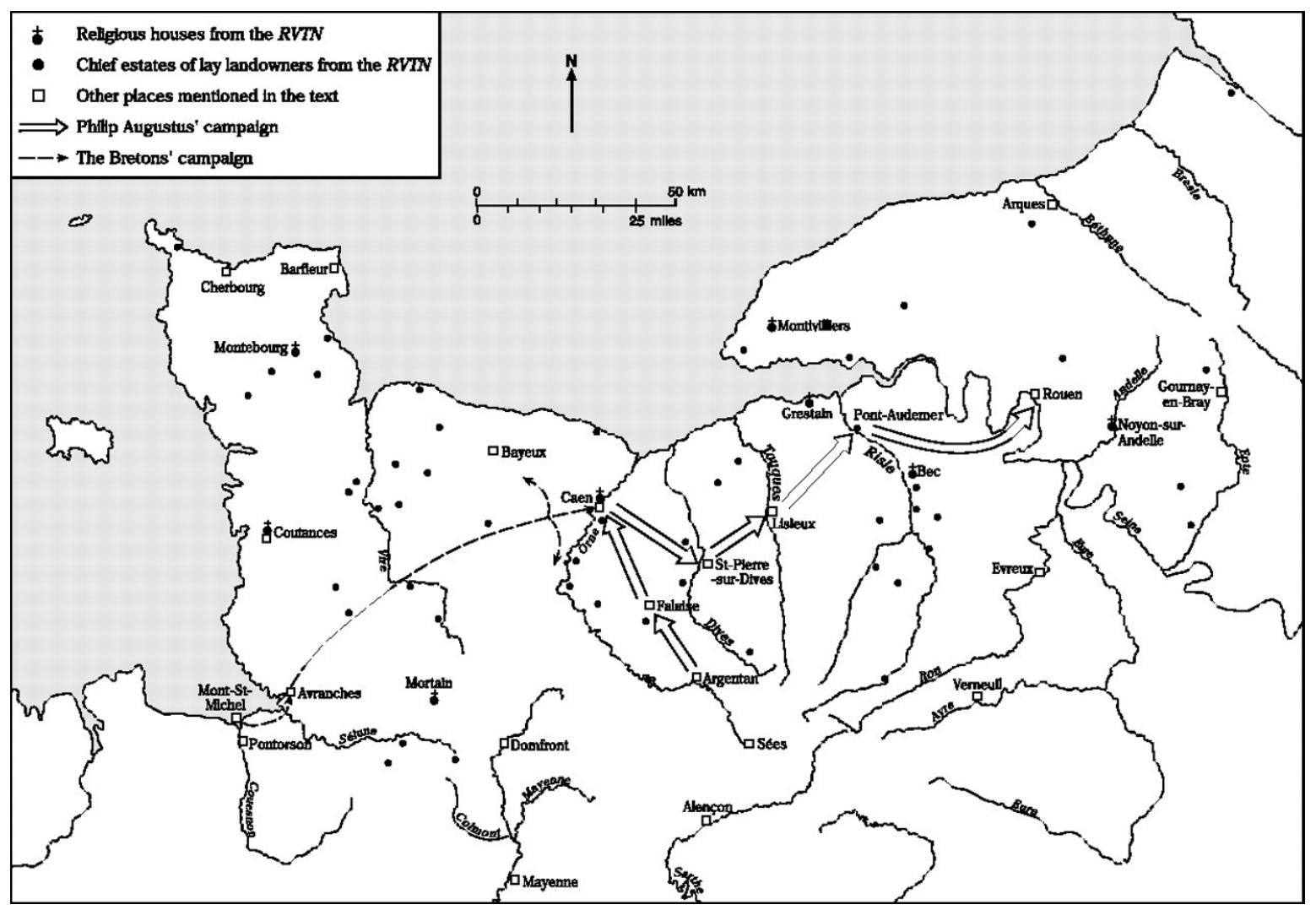


important Anglo-Norman landowners only appear indirectly in the RVTN. For instance, Hugh de Gournay's former manors of Wendover and Eaton Bray (Bucks.) are listed, but only because they had been seized from Ralph de Tilleul, to whom the king had previously committed them when they were confiscated from Gournay in $1203 .^{73}$ None of Gournay's numerous other properties were valued in the $R V T N .^{74}$ Another similar case is the lands of the Craon and Laval families, who had defected to Philip with Thouars and Mayenne, and whose former manor of Wallington (Surrey) can be found in the RVTN only because it had been granted to Luke fitzJohn, a loyalist in 1202 but who then deserted John in $1204 .^{75}$ It is therefore clear that the order for the seizure of terre Normannorum was not retrospective, that is the king did not order all of 'the lands of the Normans', including those already in the keeping of a royal official or granted out by the king, to be resumed into his hands.

This new understanding of the dating and nature of the confiscation has important consequences. It should now be clear that the $R V T N$ refers only to a very specific period of time in 1204 and, as a result, it excludes the lands of many Anglo-Norman lords whose English lands had been seized before then. This has serious implications for the use of the RVTN as a source for Anglo-Norman landholding and suggests that any analysis based on the $R V T N$ alone will significantly underestimate the extent of cross-Channel landed estates. Although this should be borne in mind, it should not preclude some tentative suggestions about the wider significance of terre Normannorum. A search of the printed sources up to 1244 has identified over 600 properties either explicitly described as terre Normannorum or held by people who were subject to confiscation, but even this is likely to be an underestimate. ${ }^{76}$ In Essex, for example, an intensive search of the available printed and manuscript sources for the thirteenth-century has identified a further twenty-nine manors that qualify as terre Normannorum according to the criteria set out above, beyond the seven listed in the $R V T N .^{77}$ This suggests that the RVTN includes at most one fifth of all terre Normannorum in Essex. If a similar level of completeness is assumed for the other counties featured in the RVTN, combined with the fact that the $R V T N$ itself only covers half of the country, it is possible to extrapolate a total of around 1,200 terre Normannorum properties in England as a whole. This may seem a large

\footnotetext{
${ }^{73} R N, 131$. For the original grant of Gournay's lands to Tilleul, see Rot. Lib., 45, 51. For the 'treason' of Hugh de Gournay in 1203, see Power, Norman Frontier, 340-2.

${ }^{74}$ In addition to Wendover and Eaton Bray, Gournay also held Caistor-on-Sea and Cantley in Norfolk (Rot. Chart., 113, 116), Pillerton Hersey in Warwickshire $(R L C, \mathrm{i}, 67)$, Houghton Regis in Bedfordshire and Mapledurham in Oxfordshire (L[iber] F[eodorum; the Book of Fees Commonly Called Testa de Nevill, Reformed from the Earliest Manuscripts] (3 vols., London, 1920-31), i, 22, 315).

${ }^{75}$ Ibid., i, 68.

${ }^{76}$ A handlist of terre Normannorum can be downloaded from http://www.hrionline.ac.uk/normans/handlist.shtml (accessed 15 December 2008). It should be stressed that this is not a complete list, and does not include many unpublished records.

${ }^{77}$ References and details for the following estates can be found in the handlist cited above: Aleford, Ashingdon, Belchamp Abbots, Bigods in Alfriston, Broxted, Chignall Smealy, Clacton, Southall in Dunmow, Dyham, Farnham, Prestead in Feering, Felsted, High Roding, Little Holland, Great Horkesley, Maldon, East Mersey, Pooley in Purleigh, White Roding, Sampford, Shopland, Stambourne, Great Tey, Tollesbury, Little Tolleshunt, Wickford, Writtle. To these can be added Bollington Hall in Ugley (H. Hall, ed., The Red Book of the Exchequer (3 vols., London, 1896), ii, 805), and property in Romford (TNA, PRO, KB 26/158, m.9d).This list does not include the lands of Henry of Essex, namely the honours of Rayleigh and Haughley, held by the countess of Perche, which comprised the Essex manors of Rayleigh, Hadleigh, Mersea, Canewdon, Eastwood, Wickford, Purleigh, Whatleys in Hadleigh, and Foulness (for a list of these estates, see Calendar of the Charter Rolls 1226-1257 (London, 1903), 12-13 and Calendar of the Patent Rolls 1232-47 (London, 1906), $100,101$.
} 
figure, but in fact it represents a very small proportion of the total number of estates in the country. To return to Essex, there were probably over 1,000 medieval manors in the county, of which between two-thirds and three-quarters were in lay hands. ${ }^{78}$ The thirty-six Essex terre Normannorum manors thus represent only about 5 per cent of the total number of manors in the hands of the gentry and aristocracy in that county.

At the same time, it is equally important not to underplay the significance of terre Normannorum. First, the above calculations only consider those Norman families who forfeited their estates in England. It seems plausible that an equal, if not greater, number of Anglo-Norman landowners would have chosen to retain their English lands and thus forfeited their estates in Normandy. Michel Nortier has identified at least 200 families who lost their Norman lands after $1204 .{ }^{79}$ It would therefore seem reasonable to assume that the above figure for the percentage of English manors affected by the severing of the cross-channel connection between England and Normandy should be raised, possibly doubled, to include those English landholders who lost lands in Normandy. Still, it is clear that the loss of Normandy only directly involved a small minority of estates. Even if relatively few gentry or even aristocratic families lost lands themselves, however, the dense network of relationships within landed society meant that many of them would have had close associates who were affected. At the same time, this provided the king with a windfall source of land. Nicholas Vincent has suggested that terre Normannorum represented 'arguably the single greatest influx of land to the crown between 1066 and the Dissolution of the monasteries ${ }^{80}$ As a result, existing local landholders would have come into contact with the new owners of these estates, for the most part men with connections to the royal court. The arrival of large numbers of 'new men' could have dramatic repercussions within local landed society, on the one hand opening new connections between centre and locality of which the ambitious could take advantage, but on the other hand raising tensions as the newcomers sought to establish and extend their local position. The seizure of terre Normannorum thus gave the English kings an opportunity both to reward their followers and to reshape landed society, and this article will now discuss John's initial use of the seized estates.

By the end of October 1204, John had made dispositions concerning the vast majority of the properties seized in May/June, and it has been argued above that it was the sheriffs' returns to these orders that provide the valuations entered in the second stage of the compilation of the RVTN. The collation of the data from the RVTN and other chancery sources that was necessary to demonstrate this point can also serve to provide the evidence for an examination of the administration of terre Normannorum in the immediate aftermath of the loss of Normandy. This can shed light on John's plans for these estates and, hopefully, his attitude towards the loss of Normandy. In essence, the king had three choices: he could retain the seized properties in his own hand and use the income therefrom to fill the war-chest that would be necessary to fund a campaign to regain his lost lands; he could restore the land to its former holder or another party with a strong claim to the land such as a family member (possibly demanding a fine); or he could grant that land to a new holder (again either in return for a fine or as a reward for service). These three options will now be examined in

\footnotetext{
${ }^{78}$ For the numbers of manors in medieval Essex, see T. K. Moore, 'Government and locality in Essex during the reign of Henry III, 1216-72' (Univ. of Cambridge Ph.D. thesis, 2006), pp.57-8. These manors have been identified from H.A. Doubleday et al, eds., The Victoria County History of Essex (10 vols., London, 1903-) and P. Morant, The History and Antiquities of the County of Essex (2 vols., London, 1768).

${ }^{79}$ Cited from Nortier's unpublished 1951 École des Chartes thesis in R. Jouet, Et la Normandie Devint Française (Paris, 1983), 74.

${ }^{80}$ Vincent, Peter des Roches, 30.
} 
turn, although it should be stressed that the peculiarities of the $R V T N$ as a source mean that it cannot be treated as a representative sample of the treatment of terre Normannorum as a whole. Moreover, there are particular difficulties in reducing the administration of estates after the confiscation to a series of neat classifications. For example, the custody of terre Normannorum held of the fee of the earl of Leicester was first granted to the earl but, after his death, some of these properties were then assigned to the royal constable of Montsorrel, one of the earl's former castles. ${ }^{81}$ Such issues are dealt with on a case-by-case basis but the figures given below should not be taken as comprehensive statements but rather as indicative of the various strategies adopted by John.

As set out above, the king's local officials, especially the sheriffs, played a central role in the seizure of terre Normannorum. Once taken into the king's hands, the property was entrusted to the keeping of four local men and the reeve who would then answer to the sheriff, a standard method of managing land in the king's hands. The names of these keepers are given in many of the RVTN entries and it seems as though it was these men who appeared before the justices to swear to the value of the land and the stock found therein. ${ }^{82}$ This was only a short-term arrangement, however, and the bulk of the estates in the RVTN were not retained in the king's own hands, but steadily dispersed. In his account before the Exchequer for 1203-4, the sheriff of Dorset and Somerset answered for Wynford Eagle, Corton Denham, Charborough and Portbury for at least part of the Exchequer year but, with the exception of Wynford Eagle, all of these had been granted out by the end of that year: Portbury on 21 July, Charborough on 8 October and Corton Denham on 22 October. ${ }^{83}$ In fact, by the end of 1204 probably only five of the more than one hundred properties listed in the RVTN remained in the keeping of the sheriffs and at least two, if not three, of these were themselves granted out in $1205 .{ }^{84}$

A further twelve $R V T N$ properties seem to have been held by royal officials other than the sheriffs. In a number of these cases, the estates of important Normans seem to have been kept together and entrusted to the custody of a leading royal favourite or official. The lands of William du Hommet came into the keeping of the royal steward Peter of Stoke, who appears in the RVTN in possession of the former Hommet manor of Whaddon (Bucks.). He was also holding Ketton (Rutl.) in September 1204 and, according to the pipe rolls, he held Stamford (Lincs.) from Easter 1204 until Easter 1205, both of which had previously been held by Hommet. In August 1206 the king appointed Walter of Preston as sheriff of Northamptonshire, and also entrusted him with the custody of the lands late of William du Hommet and Walter de Lisures, described as being formerly in Stoke's hands. ${ }^{85}$ Another example is Robert de Vieuxpont and the keeping of the lands late of Ralph Taisson. Vieuxpont was custodian of the honour of Tickhill, of which Taisson had held his northern manors of North Wheatley (Notts.) and Laughton-en-le-Morthern (Yorks.). In addition, however, Vieuxpont also held the keeping of Taisson's share of the barony of Patrixbourne (Kent), including Down Ampney (Gloucs.). ${ }^{86}$ There are no chancery records of the appointment of these men to keep these estates, and they already appear in possession in the $R V T N$ and the earliest royal

\footnotetext{
${ }^{81} R L C, \mathrm{i}, 6,7,13,104$.

${ }^{82}$ The returns from Hertfordshire and Middlesex discussed above state that the four men and the reeve had failed to come before the justices to testify as to the value of the property $(R N, 129-30)$.

${ }^{83}$ Great Roll of the Pipe 1204, 186; RLC, i, 3; RLP, 46; RLC, i, 12.

${ }^{84}$ Wynford Eagle, Benson, Wellingborough, Rothley, Winterborne Stickland. For references, see the appendix below.

${ }^{85}$ RN, 131; Great Roll of the Pipe 1204, 62; Great Roll of the Pipe 1205, 196; RLP, 67.

${ }^{86} R N, 140 ; R L C, \mathrm{i}, 9-10$. In February 1208 Brian de Lisle was ordered to take into the king's hands the lands late of Ralph Taisson, described as being formerly in the keeping of Vieuxpont (ibid., i, 104).
} 
grants, so the disposition of these estates can probably be dated to shortly after the seizure itself. Later, several RVTN properties were assigned to the castellans of Corfe and Montsorrel, presumably with the intention that the income from those estates would contribute to the running costs of those castles. ${ }^{87}$

The management of those estates retained in direct royal keeping would seem to have been supervised by a group of royal justices appointed 'to hear accounts for the lands of the Normans'. The only explicit mention of these justices is in February 1205, when they were informed by the king that Thomas Basset had taken two oxen from Islip to restock the manor of Benson (both Oxon.), but the reference to a separate terre Normannorum account roll in the Pipe Roll of 1204 suggests that they may have been active before then. ${ }^{88}$ Although detailed information about the activities of these justices is lacking, in particular whether their role was limited to hearing accounts presented by the keepers of seized properties or whether they themselves played some role in the administration of these estates, it is surely significant that the management of and accounting for terre Normannorum were kept separate from the normal royal administration. This suggests that John had a specific policy in mind for the seized properties. Unfortunately, the loss of this account roll or rolls means that it is difficult to assess the potential and actual financial value of the seized estates. As a result, it is impossible to calculate precisely the total income actually received, although we can glean some idea of the sums of money involved. According to the RVTN, which only includes a minority of the terre Normannorum, the seized properties were worth over $£ 1,640$ sterling. This total falls to $£ 526$ per annum, however, once those estates that were restored to their former holders or granted out without condition are excluded. ${ }^{89}$ This suggests that maximizing the financial return from these lands was not John's priority. The remaining RVTN properties, more than four-fifths of the total, were not kept in the king's hand, but rather either restored to their former owners or committed to new holders.

In 1204 , as in any such process of mass seizure, it was inevitable that mistakes would have been made and properties wrongly seized. It seems that such errors were quickly corrected and the properties returned to the rightful tenants. In total, twenty-nine of the properties in the RVTN were restored to their previous holders and a further eighteen were granted to other recipients who could advance strong claims to those lands. Examples from the RVTN include Chesham Higham, Fawley, Wilden and Wymington. In all four cases the tenants appear in possession of their lands soon after 1204. Elias de Beauchamp, holder of Chesham Higham before 1204, was litigating about other portions of his wife's inheritance in April 1204 and these suits were continuing in May $1205 .^{90}$ Jordan de Sauqueville, lord of Fawley, stood surety for a fine in early $1205 .{ }^{91}$ The former holder of Wilden, William de St-Rémy, was embroiled in litigation over that manor in April 1205 and still held circa $1208-9 .{ }^{92}$ Finally, in 1205 Peter de Survie paid $1 \mathrm{~m}$ scutage for his one-half fee in

\footnotetext{
${ }^{87}$ For Corfe, see ibid., i, 10, 46; and for Montsorrel, see ibid., i, 13, 23, 104, 122; Great Roll of the Pipe 1205, 36. The constable of Tickhill also collected goods and stock from North Wheatley $(R N, 141)$.

${ }^{88}$ RLC, i, 19; Great Roll of the Pipe 1204, 186.

${ }^{89}$ These figures have been calculated from the maximum values of the seized properties given in the $R N, 122-$ 43. The latter figure includes farms of $£ 15$ and $£ 80$ promised by Eustacia wife of Luke fitzJohn and the prior of Frampton respectively.

${ }^{90} C R R, \mathrm{i}, 104,323$.

${ }^{91} R O F, 247$. Sauqueville was one of William Marshal's closest followers (D. Crouch, William Marshal: Knighthood, War and Chivalry, 1147-1219 (2 $2^{\text {nd }}$ ed., Harlow, 2002), 219). He may have benefitted from his Marshal connections to maintain his interests in Normandy, where he appears in 1205 and 1220 (Power, 'French Interests of the Marshal Earls', 219-20).

${ }^{92} C R R, \mathrm{iii}, 306 ; L F, \mathrm{i}, 22$.
} 
Wymington. ${ }^{93}$ The lands of French religious houses fall into a similar category. Eleven foreign houses appear in the RVTN and nine of these houses seem to have recovered their English properties rapidly and, it seems, without having to pay a fine. ${ }^{94}$ It is significant that there are no surviving royal letters ordering the restoration of these properties. Likewise, there is no suggestion in the surviving plea rolls that any of these men had to bring suit to regain their lands. Finally, there are no indications in the fine or pipe rolls that these men had fined with the king, and John's failure to exact any financial price from these men may be taken as a tacit acknowledgement that the properties had been mistakenly seized. The most plausible explanation for all of this is that the properties were quickly restored to their holders, possibly during the process of inquiry into terre Normannorum that produced the returns entered into the first stage of the RVTN. This would also account for the absence of any enrolled orders from Chancery for the restoration or otherwise of these lands.

This includes a group of eight $R V T N$ properties that were also restored to the former tenant, but only after the proffer of a fine to the king. Examples include Roger de la Zouche (whose fine may have also covered William fitzWarin's land at Brightley), the prior of Frampton, who fined for the possession of the lands of his parent house of St-Étienne at Caen, and Eustacia wife of Luke fitzJohn who fined to regain the lands of her inheritance that had been seized from her husband. ${ }^{95}$ To these can be added a number of further examples from the fine rolls concerning properties that do not appear in the $R V T N .{ }^{96}$ Of particular interest are two cases in which the property seized by the king had recently been transferred from the previous Norman tenant to a new holder. First, William Blund of London fined to recover Easthorpe and Great Birch (Essex), which he had acquired at lease from William de Plasnes in 1203, and, second, Swan and Geoffrey of Bath fined to recover Rode (Soms.), which Ranulf Farsi had leased to them for twelve years. ${ }^{97}$ This suggests that at least some primarily Norman landowners were either using their outlying properties in England as securities for their debts or had foreseen the loss of Normandy and sought to cash in on their English estates. There are several other indications of such last minute dealings as Anglo-Norman landowners sought to cover themselves against events. ${ }^{98}$ Such fines could have been treated by John as a one-off windfall source of revenue. The total value of such fines recorded in the fine rolls between 3 June 1204 and 19 May 1205 was nearly £2,000, a useful sum but perhaps surprisingly low considering the number and value of the properties involved and in comparison to some of the other fines demanded by John. ${ }^{99}$ The relatively rapid restoration or redistribution of many of the

${ }^{93}$ Great Roll of the Pipe 1205, 74.

94 The abbeys of Bec-Hellouin, La Trinité of Caen, Cluny, Grestain, Montebourg, Mortain, Saint-Pierre-desPréaux and Saint-Leger-des-Préaux, the priory of Noyon-sur-Andelle and the canons of Coutances all seem to have recovered their lands. The exceptions were the abbey of St-Étienne, Caen, some of whose lands in England were obtained by its English cells, the priories of Frampton and Panfield (ROF, 199, Great Roll of the Pipe 1204, 33), and the abbess of Montivilliers (RLC, i, 74; RLP, 67).

${ }^{95} R O F, 199,212-13,221$.

${ }^{96}$ For example, see the fines by Helias de Marteny, Helias de Eston and Leonia widow of Robert de Étouteville (ibid., 204, 211-12, 213).

${ }^{97}$ Ibid., 206, 223.

${ }^{98}$ For example, see the exchange of lands between Elias de Wimberville and Alan Martel (ibid., 219; CRR, iv, 101-2) and the attempts of the Murdac and Tiptoft families to assign their English lands to younger sons $(R L C, \mathrm{i}, 2,3 \mathrm{~b})$. Other cases are discussed in Power, 'King John and the Norman Aristocracy', 134.

${ }^{99} £ 1,994$ in cash, as well as sixteen palfreys, one dexter and one good horse. This has been calculated from $R O F, 197-286$. For some of the other fines levied by John, see J.C. Holt, Magna Carta (2 ${ }^{\text {nd }}$ ed., Cambridge, 1992), 190-202. 
estates seized in 1204, combined with the low level of fines demanded, reinforces the hypothesis John was not primarily concerned to extracting as much money from these estates as possible.

One surprising feature of the redistribution of terre Normannorum undertaken by John is that there are few obvious examples of the transfer of lands from a Norman to the English branch of the same family. Historians have stressed the degree to which Anglo-Norman families were able to hedge their bets in times of crisis by a judicious division of loyalties, or to safeguard the interests of relatives or associates caught on the wrong side of events by securing the keeping of their lands. ${ }^{100}$ Yet there are only two examples of such intra-familial transfers from the RVTN. First, Simon fitzRoges offered $5 \mathrm{~m}$ to have Newcott in Clayhidon (Devon), which had been confiscated from William son of Simon fitzRoges. ${ }^{101}$ Meanwhile, William seems to have held the family's Norman estates, at Vrasville (MN, cant. St-Pierre-Eglise, cne. Cosqueville) and Omonville-la-Rogue (MN, cant. Beaumont). ${ }^{102}$ Second, Isabel de Mortimer, sister of Henry de Ferriéres, fined $300 \mathrm{~m}$ to have her brother's Gloucestershire manors of Lechlade and Longborough. ${ }^{103}$ Other families sought to regain possession of ancestral estates. Reginald de Moyon recovered Whichford (Warks.), which had probably been acquired by the family of the former tenant Goslin de la Pommeraye through a marriage alliance with the Moyons. ${ }^{104}$ Richard Fleming likewise made fine to recover land in Holditch (Devon) that he had earlier granted in marriage to the Saucey family. ${ }^{105}$ These cases are outnumbered by those in which seized estates were not retained within the extended family. For example, although William de Gamaches was active in John's service, fighting in royal armies in Poitou in 1205 and 1214, he did not receive his brother Matthew's confiscated estate of Church Dilwyn, which went instead to another man more prominent in royal service, William fitzWarin of Upwick. ${ }^{106}$ Even more striking is the fact that the junior English branch of the Harcourt family made no claim on the English lands of the senior Norman branch, despite the fact that William d'Harcourt of Stanton Harcourt was one of John's leading household knights and presumably wellplaced to advance such an interest. ${ }^{107}$ A final example is that the Morville family of Bradpole (Dorset) failed to secure the manor of Portbury (Soms.), lost by Herbert de Morville. ${ }^{108}$

\footnotetext{
${ }^{100}$ For the importance of family relations in general, see Power, Norman Frontier, 224-62. A specific example is the fine made in 1207 by William de Warenne to have the keeping of his brother-in-law Gilbert de Laigle's English lands (K.H. Thompson, 'The Lords of Laigle: Ambition and Insecurity on the Borders of Normandy'. Anglo-Norman Studies, xviii (1995), 192-3).

${ }^{101} R O F, 342$. William was probably Simon's own son, although the twelfth- and thirteenth-century genealogy of the fitzRoges family has not yet been conclusively established.

${ }^{102}$ Recueil des Historiens des Gaules et de la France, xxiii, 609.

${ }^{103}$ ROF, 209.

${ }^{104}$ H. A. Doubleday et al, eds., The Victoria County History of Warwick (8 vols., London and Oxford, 1902-), $\mathrm{v}, 205$.

${ }^{105} C R R$, vii, 301-2; $L F, \mathrm{I}, 612$, ii, 163. There is a discrepancy between the later two accounts. In 1237 it was said that Richard Fleming had granted the land to Richard father of William de Saucey in marriage with one of Fleming's sisters, but, according to a jury before the eyre of 1251, Richard Fleming had granted the land to William de Saucey in marriage with Joan, his daughter.

${ }^{106} R L C, \mathrm{i}, 25,28,288$. In 1216, however, as John strove to maintain the support of his household knights, he granted Stottesden (Staffs.), formerly held by Matthew, to William (ibid., i, 278). For William's continuing activity in royal service, see $R L P, 53 ; R L C, \mathrm{i}, 200-1$ and S.D. Church, The Household Knights of King John (Cambridge, 1999), 35, 42, 88 n.83, 91 n.107. For the two brothers, see LF, ii, 1270; L.C. Loyd, The Origins of Some Anglo-Norman Families, C.T. Clay and D.C. Douglas, eds. (London, 1953), 45.

${ }^{107}$ For the kinship between the two branches of the family, see D. Crouch, The Beaumont Twins: the Roots and Branches of Power in the Twelfth Century (Cambridge, 1986), 220. In 1212 William d'Harcourt may have enjoyed the custody of the Leicestershire and Warwickshire manors formerly held by the Norman branch of the family, but it is probable that he held these lands by virtue of his position as constable of
} 
Another group of people that may have been expected to have put forward their claims were the feudal lords of terre Normannorum properties. In particular, the resumption of the seized properties held of their fees would have been one way in which those Anglo-Norman magnates who chose to remain in England might have recovered some of their losses in Normandy. It seems clear, however, that the seized estates were taken directly into the king's hands rather than escheating to their feudal lords. It has already been seen that private lords do not seem to have played a significant role in the seizures of 1204, although some leading magnates later received grants of the custody of confiscated estates held of their fees. There are ten such examples from the RVTN, involving the counts or earls of Aumale, Chester, Leicester, and Norfolk as well as Robert of Berkeley and the bishop of Rochester. ${ }^{109}$ It was not automatic for lords to receive the keeping of these estates and, for example, the earl of Devon had to fine $500 \mathrm{~m}$ to have the custody of various properties held of his fee, including terre Normannorum worth $£ 20 .{ }^{110}$ Moreover, when Petronilla countess of Leicester offered $3000 \mathrm{~m}$ to have the keeping of the honour of Grandmesnil after the death of Earl Robert, the keeping of terre Normannorum was specifically excluded from the fine. ${ }^{111}$ The grant of the lands late of Robert d'Angerville to Roger Bigod, earl of Norfolk, could perhaps be interpreted as compensation for his lands in Normandy, which had recently been granted by Philip to John de Rouvray, except that Bigod, like the other magnates who received grants of terre Normannorum held of their fees, was expected to account for these lands at the Exchequer. ${ }^{112}$ As a result, he would presumably not have derived a great income from them. Unfortunately the loss of the terre Normannorum account rolls means that it is now impossible to know whether John pressed the lords to answer for these lands.

In fact, there is very little indication that any of the great English magnates received much in the way of recompense for their Norman estates. In April 1205, William de Warenne, earl of Surrey, was granted Grantham and Stamford (Lincs.) to make up for his losses overseas. ${ }^{113}$ Similarly, the grant of Bilsington (Kent) to Henry of Sandwich was described as compensation for the lands that Henry had lost in Normandy, although by 1207 the manor had been reassigned to the earl of Arundel. ${ }^{114}$ Robert de la Haye, who has not been conclusively identified, may provide a third casestudy. He was granted land worth $£ 30$ in Princes Risborough (Bucks.) and this grant mentions that Robert is to have the chief messuage to accommodate his wife and children, which suggests that

\footnotetext{
Montsorrel, in the same way as his predecessor in that office, Ivo de Vieuxpont $(R L C, \mathrm{i}, 122)$.

${ }^{108}$ The best account of the various branches of the Morville family can be found in N.C. Vincent, 'The Murderers of Thomas Becket', N. Fryde and D. Reitz, eds., Bischofsmord in Mittelalter (Göttingen, 2003), 223-9. There remains more work to be done on the West Country branches of the family, but there were certainly some connections between the Bradpole and Portbury branches.

${ }^{109}$ The count of Aumale received the keeping of Borley (Essex) and other lands held of his fee by Robert Bertrand in Suffolk and Hampshire $(R L C, \mathrm{i}, 19)$; the earl of Chester was granted the keeping of terre Normannorum in Northamptonshire held of his fee, presumably including Mears Ashby (ibid., i, 11); the examples of Robert d'Harcourt and Robert de Thibouville, William d'Angerville and Geoffrey de Bosco have been discussed above. The final example is reversed, since the Morvilles were actually the Berkeley's feudal lords for Portbury (B. Wells-Furby, ed., A Catalogue of the Medieval Muniments at Berkeley Castle (2 vols., Bristol, 2004), ii, 528).

${ }^{110} R O F, 235-6$.

${ }^{111}$ Ibid., 226.

${ }_{112} R L C, \mathrm{i}, 12,24$. Recueil des Actes de Philip Auguste, ii, 374-5.

${ }^{113}$ Histoire des Ducs, 99-100; RLC, i, 28.

${ }^{114}$ Ibid., i, 9, 94.
} 
they had been deprived of their previous residence. ${ }^{115}$ The former tenant of Princes Risborough, William de Semilly, was the head of a cadet branch of the Hommet family, which was related by marriage to the de la Haye family of La Haye-du-Puits. The provision for Robert at Princes Risborough may indicate some connection to the family of La Haye-du-Puits, although this is hardly conclusive. ${ }^{116}$ These are the only such examples that have been found, however, which is striking given the number of important magnates and courtiers who had lost lands in Normandy. This seems to have been deliberate royal policy, perhaps to ensure that the magnates were sufficiently motivated to support the king's attempts to recover his lost continental territories and, with them, their own lands.

The remaining forty $R V T N$ properties were granted out by John to a number of different people on a variety of terms. There are two isolated examples in June, but most of these grants date from late July onwards, after the first returns from the inquiry into terre Normannorum. ${ }^{117}$ The greatest prizes naturally went to those closest to the king. The bulk of the lands late of the count of Perche, including Newbury (Berks.), were granted to the king's illegitimate son Geoffrey. ${ }^{118}$ The extensive lands of Robert fitzErneis, lying in Essex, Lincolnshire and Norfolk, ended up in the hands of Geoffrey fitzPeter, the justiciar and earl of Essex. This transaction remains shrouded in mystery as there is no surviving documentary evidence of the original grant of these lands to fitzPeter. ${ }^{119}$ The fate of the extensive lands of Thomas de St-Valéry, lying mainly in Middlesex and Oxfordshire, is equally murky. There is no mention in the RVTN of any of the St-Valéry properties in Oxfordshire, and the jurors of Middlesex failed to come before the justices to give a valuation of the St-Valéry estates in that county. ${ }^{120}$ Moreover, it seems that at least some of the family's lands in England were entrusted to the keeping of Hubert Walter, the chancellor and archbishop of Canterbury, who was to hold them by paying $100 \mathrm{~m}$ per annum to Henry de St-Valéry, brother of Thomas. This may have been an attempt to avoid the confiscation of the St-Valéry's English lands and the key to its success, where other similar attempts had failed, was that the St-Valérys had enlisted the support of one of the most prominent and influential men at John's court. ${ }^{121}$ Finally, William Marshal, earl of

\footnotetext{
115 Ibid., i, 8-9.

${ }^{116}$ Robert was probably the son of Ralph de la Haye (fl. 1143-72), younger brother of Richard de la Haye lord of La Haye-du-Puits. Semilly and de la Haye were therefore not directly related but, if this reconstruction is correct, then both were first cousins once removed of the younger William du Hommet. I am grateful to Daniel Power for this information.

117 The only grants of terre Normannorum made in June were to William de Briouze of the lands held of his fee by Roger de la Zouche in Shropshire, and to Robert de Ropsley of the manors of Wikes and Donnington (Lincs.) late of Brice the Chamberlain $(R L C, \mathrm{i}, 1)$.

${ }^{118}$ Ibid., i, 3. Another former Percheron manor, Toddington (Beds.) appears in the RVTN in the possession of Peter des Roches, then rising in royal service, and it is not clear whether Peter was dispossessed in favour of Geoffrey.

${ }^{119}$ In addition to Debden and Hatfield Peverel (Essex), which appear in the $R V T N(R N, 128)$, Robert fitzErneis also held at Bucknall, Hemingby and Horsington in Lincolnshire, and Great Massingham, Wells and Warham in Norfolk $(L F, \mathrm{i}, 169,388,619)$. The first explicit mention of this grant is in November 1213, when John confirmed to William de Mandeville the lands late of Robert fitzErneis, to hold of the king in chief as William's father, Geoffrey fitzPeter, had done before $(R L C, \mathrm{i}, 154)$,

${ }^{120} R N, 130$.

${ }^{121} R L C, \mathrm{i}, 43$. This arrangement seems to refer only to the Oxfordshire lands of the St-Valérys, and the fate of the family properties in Middlesex and Gloucestershire is uncertain. Meanwhile, there is some evidence that Thomas remained in royal favour after the loss of Normandy. On 14 August 1204 he was pardoned 10m that he owed the king and in October he was granted royal letters of simple protection (ibid., i, 8; $R L P$, 46).Intriguingly, in March 1205 he received licence to import ten tuns of wine that he had promised to the king, Hubert Walter and Geoffrey fitzPeter, possibly as a literal sweetener $(R L P, 52)$.
} 
Pembroke, eventually secured the manor of Sturminster Marshall, formerly held by Robert count of Meulan. ${ }^{122}$

Other significant figures at court also secured the keeping of eight $R V T N$ estates. The household steward William de Cantiloupe acquired RVTN properties at Cotheridge and Wychbold (Worcs.), as well as lands at Aston Cantlow (Warks.) and Milston (Wilts.). ${ }^{123}$ The fitzGerald family had a longstanding connection to the royal household and Warin fitzGerald received the keeping of Down Ampney (Gloucs.). ${ }^{124}$ Geoffrey de Lucy, the nephew of the bishop of Winchester and royal familiar Godfrey de Lucy, received Hailes (Gloucs.). ${ }^{125}$ John fitzHugh and William of Wrotham, two of John's leading administrators, were granted land worth $£ 20$ (later increased to £30) in Kirtlington (Oxon.) and 100s rent in Dartford (Kent) respectively. ${ }^{126}$ On a less exalted level, one of the keepers of the king's falcons, Roger de Caux, was rewarded with land in Tattenhoe and Lillingstone Lovell and the king's sauser Geoffrey received $£ 5$ land in Grendon Underwood (all Bucks.). ${ }^{127}$ Some of these grants to courtiers or royal servants may have exchanged money fees or payments owed by the king for land. For example, Geoffrey de Jorz and Richard of Laxton were granted land worth $£ 20$ from the estate late of Roger de Fonteines in Carlton on Trent and Darlton (Notts.). The terms of this grant are interesting. Geoffrey and Richard were to answer for a farm of $10 \mathrm{~m}$ at the Exchequer, and the king was also to be quit of the shillings and liberaciones (daily wages) that he had promised them. ${ }^{128}$ The conversion of monetary payments into land was standard royal practice to reward service and the provision for Geoffrey and Richard is only unusual in spelling out the reason for the grant. ${ }^{129}$ As with the assignment of seized properties to the constables of Corfe and Montsorrel, it seems that John was using terre Normannorum to defray the expenses of his government. This policy had the dual advantages of reducing the burden on the royal purse while still maintaining the king's freedom of manoeuvre regarding the future of those estates.

Perhaps the crucial point to observe is that none of the arrangements for terre Normannorum put in place in 1204 proved particularly long-standing. In this respect, it is significant that the distribution of the seized properties was recorded in the close rolls rather than the charter rolls. Such dispositions were not made by charter, because they are were not intended to be solemn grants in perpetuity or in hereditary right. Rather they were temporary administrative measures and executed

${ }^{122} C R R, \mathrm{i}, 124 ; R L C, \mathrm{i}, 6 ; R L P, 45$. Crouch, William Marshal, 95-6.

${ }^{123} R L C, \mathrm{i}, 5,8,9$.

${ }^{124}$ Ibid., i, 6, 8, 9-10. For the longstanding relationship between the fitzGeralds and successive kings, see N.C. Vincent, 'Warin and Henry fitz Gerald, the King's Chamberlains: the Origins of the FitzGeralds Revisited', Anglo-Norman Studies, xxi (1998), 233-60, esp. 239.

${ }^{125} R L C, \mathrm{i}, 12 ; L F, \mathrm{i}, 51$. For the identity of this Geoffrey de Lucy, see M.C. Cheney, 'Master Geoffrey de Lucy, an Early Chancellor of the University of Oxford', ante, lxxii (1967), p.758. As previously discussed, Geoffrey also held the keeping of Black Torrington and King's Nympton, late of Juhel de Mayenne $(R L C$, i, $1)$.

${ }^{126}$ For the grant to fitzHugh, see $R L C, \mathrm{i}, 14,35$; and for that to Wrotham, see ibid., i, 18; Great Roll of the Pipe 1204, 212; LF, i, 269. These two men were described by Sidney Painter as among John's leading administrators (S. Painter, The Reign of King John (Baltimore, 1949), 80-1).

${ }^{127} R L C, \mathrm{i}, 9,16,17$. For the falconry sergeanty held by the Caux family, see W. Page, ed., The Victoria County History of Buckingham (4 vols., London, 1905-28), iv, 277-8.

${ }^{128} R L C, \mathrm{i}, 11$. This implies that Geoffrey and Roger were receiving liberaciones worth $20 \mathrm{~m}$ in total, or $10 \mathrm{~m}$ each, per annum, equivalent to a daily wage of just under $4 \frac{1}{2} \mathrm{~d}$.

${ }^{129}$ Church, Household Knights, 81-94. Church does not note the example of Jorz and Laxton (because although royal servants they do not appear in lists of household knights) but it supports his argument that wages were generally a temporary means of reward until some more permanent benefit could be provided. 
by letters close, the instrument par excellence for such routine matters. This highlights their essentially short-term and provisional nature, which was later encapsulated in the various conditional phrases attached to grants of terre Normannorum property. The only exceptions to this from the RVTN were the lands of Robert fitzErneis, which Geoffrey fitzPeter and his heirs retained, and Dartford, which William of Wrotham had granted to the Hospitallers. ${ }^{130}$ In both of these cases the initial grants may not have been intended as permanent. William de Cantiloupe also managed to hang on to Aston Cantlow and, indeed, it is from his family that the parish derives its suffix. More than anything, however, this reflects the extraordinary longevity of successive generations of the Cantiloupe family in royal service under both John and Henry III. ${ }^{131}$ This desire to keep his options open is perhaps the key to understanding John's policy. If he were to make valuable grants of terre Normannorum in hereditary fee, it would in fact provide a powerful disincentive for the recipients of such grants to support the expensive campaigns on the continent that would be necessary to recover the lost provinces, since the reunification of England and Normandy would allow the dispossessed former holders to reclaim the seized estates.

As this close reading of the RVTN has established, the 'general order concerning the lands of the Normans' was issued in late May 1204 and ordered the seizure of the English properties of those Anglo-Norman landholders who were believed to have come to terms with Philip Augustus during his procession across Normandy during that month, rather than a comprehensive measure targeting all the lands that would later come to be classified as terre Normannorum. The order specifically enjoined the seizure of those estates pending inquiry rather than the strict confiscation of those lands. It also seems that terre Normannorum were kept apart from the normal royal administration as the accounts for the seized properties were heard before special justices and recorded on a separate roll. Finally, these lands were only distributed in temporary custody rather than granted out permanently. At the end of 1204, therefore, John had yet to commit himself to any permanent solution, as this might have been seen as a tacit recognition that the loss of Normandy was more than just a short-term reverse. It was this determination to restore his family's position on the continent that drove John's increasingly harsh and exploitative government in England in the decade after 1204, and the collapse of his hopes at Bouvines in 1214 that left him at the mercy of the opposition to his rule and led ultimately to Magna Carta. ${ }^{132}$

\section{University of Reading}

\section{TONY K. MOORE}

\footnotetext{
${ }^{130}$ It should be noted that, when the Mandeville estates were declared confiscate during the Magna Carta civil war, John restored these lands to Robert fitzErneis in return for a fine of $200 \mathrm{~m}$ and two palfreys $(R O F, 576)$. Later, Robert's younger brother William fitzErneis, who fought for John in the civil war, was granted his brother's estates $(R L C, \mathrm{i}, 313,321,442)$. In practice, William may not have succeeded in recovering seisin of these estates from William de Mandeville, as in 1221 he was suing Mandeville for the manors of Debden and Hatfield Peverel $(C R R, \mathrm{x}, 75)$. Interestingly, a small estate in Hatfield Peverel was later held by a certain Philip fitzErneis and, after him, by his own son, another Philip (TNA, PRO, JUST 1/229, m.14d; TNA, PRO, KB 26/147B, m.9). For the grant by Wrotham to the Hospitallers, see $L F$, i, 269.

${ }^{131}$ For a brief account of the Cantiloupe family and their connection to the manor of Aston Cantlow, see The Victoria History of the County of Warwick, iii, 36.

${ }^{132}$ Holt, Magna Carta, 188-93 and 221-3.
} 


\section{Appendix}

Unless otherwise specified, all references to the dates of royal orders can be found in $R L C, \mathrm{i}, 1-12$. Dates marked with an asterix include orders for valuation of the land and/or stock and crops.

\begin{tabular}{|c|c|c|c|c|}
\hline County & Place & Former tenant & New tenant & $\begin{array}{l}\text { Date of royal } \\
\text { orders }\end{array}$ \\
\hline Worcs. & Cotheridge & $\begin{array}{l}\text { Roger de } \\
\text { Etmondeville }\end{array}$ & William de Cantiloupe & 15 August \\
\hline Worcs. & Wychbold & $\begin{array}{l}\text { Roger de } \\
\text { Etmondeville }\end{array}$ & William de Cantiloupe & 15 August \\
\hline Dorset & Spetisbury & $\begin{array}{l}\text { Abbey of St- } \\
\text { Pierre-des- } \\
\text { Préaux }\end{array}$ & Restored & \\
\hline Dorset & Stourpaine & $\begin{array}{l}\text { Abbey of } \\
\text { Saint-Leger- } \\
\text { des-Préaux }\end{array}$ & Restored & \\
\hline Dorset & Povington in Tyneham & Bec Abbey & Restored & \\
\hline Dorset & Milbourne Bec & Bec Abbey & Restored & \\
\hline Dorset & Winterborne Stickland & \begin{tabular}{|l|} 
Canons of \\
Coutances
\end{tabular} & Sheriff & \\
\hline Dorset & Friars Waddon & $\begin{array}{l}\text { Montivilliers } \\
\text { Abbey }\end{array}$ & Sheriff & \\
\hline Dorset & Wynford Eagle & $\begin{array}{l}\text { Gilbert de } \\
\text { Laigle }\end{array}$ & Sheriff & \\
\hline Dorset & Loders & $\begin{array}{l}\text { Montebourg } \\
\text { Abbey }\end{array}$ & Restored & \\
\hline Dorset & Hinton Waldrist & \begin{tabular}{|l} 
Monks of \\
Mortain
\end{tabular} & Restored & \\
\hline Dorset & Church Knowle & $\begin{array}{l}\text { Robert de } \\
\text { Thibouville }\end{array}$ & Constable of Corfe & 4 October \\
\hline Dorset & Tarrant Launceston & \begin{tabular}{|l|} 
Abbey of La \\
Trinité de Caen
\end{tabular} & Restored & \\
\hline Dorset & Frampton & $\begin{array}{l}\text { Abbey of St- } \\
\text { Étienne de } \\
\text { Caen }\end{array}$ & Frampton Priory & \\
\hline Dorset & Sturminster Marshall & $\begin{array}{l}\text { Count of } \\
\text { Meulan }\end{array}$ & $\begin{array}{l}\text { Countess of } \\
\text { Meulan/Thomas de } \\
\text { Rochford/William } \\
\text { Marshal, earl of } \\
\text { Pembroke }\end{array}$ & $\begin{array}{l}23 \text { August/9 } \\
\text { September* }\end{array}$ \\
\hline Soms. & Norton-sub-Hamdon & $\begin{array}{l}\text { Grestain } \\
\text { Abbey }\end{array}$ & Restored & \\
\hline Soms. & Corton Denham & Peter de St- & William de Greinville & 22 October \\
\hline
\end{tabular}




\begin{tabular}{|c|c|c|c|c|}
\hline & & Hilaire & & \\
\hline Soms. & Hemington & $\begin{array}{l}\text { William de } \\
\text { Préaux }\end{array}$ & Roger de Punchardon & 23 July \\
\hline Soms. & Rode & Ranulf Farsi & $\begin{array}{l}\text { Swan and Geoffrey of } \\
\text { Bath }\end{array}$ & \\
\hline Soms. & Newton St Loe & $\begin{array}{l}\text { Robert de St- } \\
\text { Lô }\end{array}$ & William le Gros & 3 August \\
\hline Soms. & Portbury & \begin{tabular}{|l|} 
Herbert de \\
Morville
\end{tabular} & Robert de Berkelay & 21 July \\
\hline Soms. & Ston Easton & \begin{tabular}{|l} 
Alexander de \\
Rouelle
\end{tabular} & Unknown & \\
\hline Soms. & Whatley & & Unknown & \\
\hline Essex & Bradwell-on-Sea & $\begin{array}{l}\text { William } \\
\text { Bacon, Robert } \\
\text { de St-Remy }\end{array}$ & Unknown & \\
\hline Essex & Easthorpe and Great Birch & $\begin{array}{l}\text { William de } \\
\text { Plasnes }\end{array}$ & Restored & 3 August \\
\hline Essex & Hatfield Peverel & $\begin{array}{l}\text { Robert } \\
\text { fitzErneis }\end{array}$ & Geoffrey fitzPeter & \\
\hline Essex & Debden & $\begin{array}{l}\text { Robert } \\
\text { fitzErneis }\end{array}$ & Geoffrey fitzPeter & \\
\hline Essex & Stebbing & \begin{tabular}{|l} 
Hugh de \\
Colounces
\end{tabular} & William of Wrotham & \\
\hline Essex & Borley & \begin{tabular}{|l} 
Robert de \\
Thibouville
\end{tabular} & & $\begin{array}{l}7 \text { February } \\
1205(R L C, \mathrm{i} \\
19)\end{array}$ \\
\hline Herts. & Lilley and Willian & $\begin{array}{l}\text { William Malet } \\
\text { de Graville }\end{array}$ & Matthew of Lilley & \\
\hline Herts. & Southall in Great Gatesden & \begin{tabular}{|l|} 
Gilbert \\
Malesmains
\end{tabular} & Geoffrey fitzPeter & \\
\hline Middlx. & $\begin{array}{l}\text { Unspecified [Edgware, } \\
\text { Stanmore Chenduit in } \\
\text { Little Stanmore and } \\
\text { Kingsbury] }\end{array}$ & $\begin{array}{l}\text { Gilbert } \\
\text { Malesmains }\end{array}$ & Geoffrey fitzPeter & \\
\hline Middlx. & $\begin{array}{l}\text { Unspecified [Isleworth and } \\
\text { Hampton with the villages } \\
\text { of Heston and } \\
\text { Twickenham] }\end{array}$ & $\begin{array}{l}\text { Thomas de St- } \\
\text { Valéry } \\
\end{array}$ & Hubert Walter & \\
\hline Devon & Highweek alias Teignweek & Luke fitzJohn & Eustacia de Courtenay & 15 August \\
\hline Devon & Diptford & Luke fitzJohn & Eustacia de Courtenay & 15 August \\
\hline Devon & Oburnford & Luke fitzJohn & Eustacia de Courtenay & 15 August \\
\hline Devon & West Alvington & $\begin{array}{l}\text { Oliver } \\
\text { d'Aubigne }\end{array}$ & William de la Ferte & 22 October \\
\hline
\end{tabular}




\begin{tabular}{|c|c|c|c|c|}
\hline Devon & North Molton & $\begin{array}{l}\text { Roger de la } \\
\text { Zouche }\end{array}$ & Restored & \\
\hline Devon & \begin{tabular}{|l} 
Brightley in \\
Chittlehampton
\end{tabular} & $\begin{array}{l}\begin{array}{l}\text { William } \\
\text { fitzWarin }\end{array} \\
\end{array}$ & Restored & \\
\hline Devon & Holditch in Thorncombe & $\begin{array}{l}\text { William de } \\
\text { Saucey }\end{array}$ & Richard Fleming & \\
\hline Devon & Rewe & \begin{tabular}{|l|} 
Gilbert de \\
Villers
\end{tabular} & Robert de Secqueville & \\
\hline Devon & Dunsford & William Bacon & Robert de Secqueville & \\
\hline Devon & Newcott in Clayhidon & $\begin{array}{l}\text { William } \\
\text { fitzSimon } \\
\text { fitzRoges }\end{array}$ & Simon fitzRoges & \\
\hline Beds. & Wilden & $\begin{array}{l}\text { William de St- } \\
\text { Rémy }\end{array}$ & Restored & \\
\hline Beds. & Wilden & $\begin{array}{l}\text { Robert de St- } \\
\text { Rémy }\end{array}$ & James de Clare & 14 October \\
\hline Beds. & Wymington & Peter Survie & Restored & \\
\hline Beds. & Eaton Bray & $\begin{array}{l}\text { Ralph de } \\
\text { Tilleul }\end{array}$ & Sibyl de Fiennes & \\
\hline Beds. & Toddington & $\begin{array}{l}\text { Countess of } \\
\text { Perche }\end{array}$ & Peter des Roches & \\
\hline Bucks. & Grendon Underwood & \begin{tabular}{|l|} 
Robert de \\
Thibouville
\end{tabular} & $\begin{array}{l}\text { Geoffrey the king's } \\
\text { sauser }\end{array}$ & 19 September \\
\hline Bucks. & Wendover & \begin{tabular}{|l} 
Ralph de \\
Tilleul
\end{tabular} & Sibyl de Fiennes & \\
\hline Bucks. & Princes Risborough & $\begin{array}{l}\text { William de } \\
\text { Semilly }\end{array}$ & Robert Delahaye & 16 September \\
\hline Bucks. & Chesham Higham & \begin{tabular}{|l} 
Elias de \\
Beauchamp
\end{tabular} & Restored & \\
\hline Bucks. & Fawley & $\begin{array}{l}\text { Jordan de } \\
\text { Sauqueville }\end{array}$ & Restored & \\
\hline Bucks. & Lower Winchendon & \begin{tabular}{|l} 
Robert de \\
Brencourt
\end{tabular} & Notley Abbey & \\
\hline Bucks. & Tattenhoe & Ralph Martel & Roger de Caux & $\begin{array}{l}\text { 25 December } \\
(R L C, \mathrm{i}, 16)\end{array}$ \\
\hline Bucks. & Whaddon & $\begin{array}{l}\text { William du } \\
\text { Hommet }\end{array}$ & Peter of Stoke & \\
\hline Bucks. & Crafton in Wing & Ralph le Bret & Unknown & \\
\hline Oxon. & Kirtlington & \begin{tabular}{|l} 
William du \\
Hommet
\end{tabular} & $\begin{array}{l}\text { Geoffrey Savage/John } \\
\text { fitzHugh }\end{array}$ & $\begin{array}{l}14 \text { November } \\
(R L C, \mathrm{i}, 14)\end{array}$ \\
\hline Oxon. & Benson & $\begin{array}{l}\text { Robert } \\
\text { d'Harcourt }\end{array}$ & Thomas Basset & $\begin{array}{l}9 \text { February } \\
1205(R L C, \mathrm{i}, \\
19)\end{array}$ \\
\hline
\end{tabular}




\begin{tabular}{|c|c|c|c|c|}
\hline Berks. & Newbury & $\begin{array}{l}\text { Countess of } \\
\text { Perche }\end{array}$ & $\begin{array}{l}\text { Geoffrey } \\
\text { fitzRoy/Simon of } \\
\text { Pattishall }\end{array}$ & 24 July \\
\hline Surrey & Gomshall Netley & Eustace de Es & Restored & \\
\hline Surrey & Beddington & Eustace de Es & Restored & \\
\hline Surrey & Headley & $\begin{array}{l}\text { Thomas } \\
\text { Malesmains }\end{array}$ & $\begin{array}{l}\text { Richard de Clare, earl } \\
\text { of Gloucester }\end{array}$ & $\begin{array}{l}14 \text { November } \\
(R L C, \mathrm{i}, 14)\end{array}$ \\
\hline Surrey & Wallington in Beddington & Luke fitzJohn & Eustacia de Courtenay & 15 August \\
\hline Northants. & Easton-on-the-Hill & $\begin{array}{l}\text { William du } \\
\text { Hommet }\end{array}$ & Simon of Lindon & 4 June \\
\hline Northants. & Grafton Underwood & $\begin{array}{l}\text { William du } \\
\text { Hommet }\end{array}$ & Peter of Stoke & \\
\hline Northants. & Duddington & Fulk Paynel & Gerard de Canville & $\begin{array}{l}25 \text { April } 1205 \\
(R L C, \mathrm{i}, 28)\end{array}$ \\
\hline Northants. & Mears Ashby & $\begin{array}{l}\text { William du } \\
\text { Hommet }\end{array}$ & $\begin{array}{l}\text { Ranulf de Blundeville, } \\
\text { earl of Chester }\end{array}$ & 13 October* \\
\hline Northants. & Blatherwick & $\begin{array}{l}\text { Odo le } \\
\text { Bouteiller de } \\
\text { Lestre }\end{array}$ & Unknown & \\
\hline Northants. & Wellingborough & $\begin{array}{l}\text { Robert } \\
\text { d'Harcourt }\end{array}$ & Philip of Worcester & $\begin{array}{l}8 \text { August } \\
1205^{*}(R L C, \mathrm{i}, \\
45)\end{array}$ \\
\hline Northants. & Stoke Bruerne & $\mid$ John de Préaux $\mid$ & Unknown & \\
\hline Berks. & Woolley in Chaddleworth & $\begin{array}{l}{[\text { Montebourg }} \\
\text { Abbey] }\end{array}$ & Restored & \\
\hline Berks. & Priors in Aston Tirrold & $\begin{array}{l}\text { Abbey of } \\
\text { Saint-Pierre- } \\
\text { des-Préaux }\end{array}$ & Restored & \\
\hline Berks. & Letcombe Regis & Cluny Abbey & Restored & \\
\hline Berks. & Beckett in Shrivenham & Noyon Priory & Restored & \\
\hline Berks. & Shrivenham & $\mid[$ Noyon Priory] $\mid$ & Restored & \\
\hline Berks. & Hanney (East or West) & [Noyon Priory] & Restored & \\
\hline Berks. & East Henred & Noyon Priory & Restored & \\
\hline Berks. & Shilton & John de Préaux & Beaulieu Abbey & 28 July \\
\hline Warks. & Ilmington & \begin{tabular}{|l} 
Robert d' \\
Harcourt
\end{tabular} & Owain ap Dafydd & 14 October * \\
\hline Warks. & $\begin{array}{l}\text { Wilmcote in Aston } \\
\text { Cantlow }\end{array}$ & $\begin{array}{l}\text { Brice the } \\
\text { Chamberlain }\end{array}$ & Unknown & 22 September* \\
\hline Warks. & Atherstone & $\begin{array}{l}\text { Ralph de } \\
\text { Rupierre }\end{array}$ & The Templars & 3 August* \\
\hline Warks. & Whichford & $\begin{array}{l}\text { Gollin de } \\
\text { Pommeraye }\end{array}$ & Reginald de Moyon & 21 September* \\
\hline Leics. & Birstall, Cadeby, Leicester & Robert & Robert de Breteuil, & 8 September $/ 27$ \\
\hline
\end{tabular}




\begin{tabular}{|c|c|c|c|c|}
\hline & & d'Harcourt & $\begin{array}{l}\text { earl of Leicester/Ivo de } \\
\text { Vieuxpont }\end{array}$ & October* \\
\hline Leics. & Sileby & $\begin{array}{l}\text { Robert } \\
\text { d'Harcourt }\end{array}$ & $\begin{array}{l}\text { Robert de Breteuil, } \\
\text { earl of Leicester/Ivo de } \\
\text { Vieuxpont }\end{array}$ & \begin{tabular}{|l}
8 September/27 \\
October*
\end{tabular} \\
\hline Leics. & Rothley & $\begin{array}{l}\text { John } \\
\text { d'Harcourt }\end{array}$ & Ivo de Vieuxpont & $\begin{array}{l}19 \text { March } 1205 \\
(R L C, \mathrm{i}, 23)\end{array}$ \\
\hline Leics. & Syston & $\begin{array}{l}\text { Robert de } \\
\text { Thibouville }\end{array}$ & $\begin{array}{l}\text { Thomas Basset/ } \\
\text { Robert de Breteuil, } \\
\text { earl of Leicester/Ivo de } \\
\text { Vieuxpont }\end{array}$ & $\begin{array}{l}24 \text { August*/8 } \\
\text { September/27 } \\
\text { October* }\end{array}$ \\
\hline Leics. & Ilston-on-the-Hill & John de Joye & Hugh of Chacombe & $\begin{array}{l}29 \text { January } \\
1205(R L C, \mathrm{i}, \\
18)\end{array}$ \\
\hline Leics. & Ashby-de-la-Zouch & $\begin{array}{l}\text { Roger de la } \\
\text { Zouche }\end{array}$ & Restored & \\
\hline Leics. & $\begin{array}{l}\text { Old Ingarsby and } \\
\text { Willoughby Waterless }\end{array}$ & $\begin{array}{l}\text { Robert d' } \\
\text { Angerville }\end{array}$ & $\begin{array}{l}\text { Roger Bigod, earl of } \\
\text { Norfolk }\end{array}$ & 18 October* \\
\hline Kent & Patrixbourne & Ralph Taisson & Reginald of Cornhill & 18 September* \\
\hline Kent & River & Ralph Taisson & Reginald of Cornhill & 18 September* \\
\hline Kent & River & John de Préaux & Sheriff & \\
\hline Kent & Sutton-at-Hone in Dartford & Robert Bacon & William of Wrotham & $\begin{array}{l}5 \text { February } \\
1205(R L C, \mathrm{i}, \\
18)\end{array}$ \\
\hline Kent & Littlebrook & $\begin{array}{l}\text { Geoffrey de } \\
\text { Bosco }\end{array}$ & Bishop of Rochester & 15 August* \\
\hline Kent & Bilsington & \begin{tabular}{|l} 
Robert de \\
Courcy
\end{tabular} & Henry of Sandwich & 30 September \\
\hline Kent & Great Delce & $\begin{array}{l}\text { Geoffrey de } \\
\text { Bosco }\end{array}$ & Reginald of Cornhill & $\begin{array}{l}10 \text { December } \\
1205\end{array}$ \\
\hline Dorset & Charborough & $\begin{array}{l}\text { Robert } \\
\text { d'Harcourt }\end{array}$ & Constable of Corfe & $\begin{array}{l}8 \text { October } \\
(R L P, 46)\end{array}$ \\
\hline Dorset & Sturminster Marshall & \begin{tabular}{|l|} 
Count of \\
Meulan
\end{tabular} & $\begin{array}{l}\text { William Marshal, earl } \\
\text { of Pembroke }\end{array}$ & 9 September* \\
\hline Dorset & Charlton Marshall & & & \\
\hline Dorset & Erwent & & & \\
\hline Dorset & Meleburn & & & \\
\hline Notts. & North Wheatley & Ralph Taisson & Geoffrey de Lucy & 27 September* \\
\hline Notts. & Bingham & Fulk Paynel & Robert de Gaugy & 22 August* \\
\hline Berks. & South Fawley & \begin{tabular}{|l|} 
Ernald de \\
Maune \\
\end{tabular} & Restored & 8 September \\
\hline Gloucs. & Hailes & $\begin{array}{l}\text { Chamberlains } \\
\text { of Tancarville }\end{array}$ & Constable of Tickhill & 20 October* \\
\hline
\end{tabular}




\begin{tabular}{|c|c|c|c|c|}
\hline Oxon. & Attingdon in Thame & $\begin{array}{l}\text { Odo de } \\
\text { Brémontier }\end{array}$ & Henry de Colville & $\begin{array}{l}22 \text { February } \\
1205(R L C, \mathrm{i} \\
20)\end{array}$ \\
\hline Berks. & Newbury & $\begin{array}{l}\text { Count of } \\
\text { Perche }\end{array}$ & & 23 July \\
\hline-- & Lendend & $\begin{array}{l}\text { Abbey of St- } \\
\text { Étienne de } \\
\text { Caen }\end{array}$ & Unknown & \\
\hline Berks. & $\begin{array}{l}\text { [Basildon and } \\
\text { Ashampstead] }\end{array}$ & $\begin{array}{l}\text { William de } \\
\text { Fruges }\end{array}$ & Restored & \\
\hline Berks. & Shilton & John de Préaux & & 28 July \\
\hline Gloucs. & Down Ampney & $\begin{array}{l}\text { John de Préaux } \\
\text { and Ralph } \\
\text { Taisson }\end{array}$ & Warin fitzGerold & 12 September* \\
\hline [Gloucs./Rutl.] & $\begin{array}{l}\text { [Lechlade and } \\
\text { Longborough/possibly } \\
\text { Oakham] }\end{array}$ & $\begin{array}{l}\text { Henry de } \\
\text { Ferrières }\end{array}$ & Isabel de Ferrières & \\
\hline Herefs. & Church Dilwyn & $\begin{array}{l}\text { Matthew de } \\
\text { Gamaches }\end{array}$ & $\begin{array}{l}\text { William fitzWarin of } \\
\text { Upwick }\end{array}$ & $\begin{array}{l}1 \text { April } 1205 \\
(R L C, \mathrm{i}, 25)\end{array}$ \\
\hline
\end{tabular}

